\title{
Article \\ Effect of Platform Temperature and Post-Processing Heat Treatment on the Fatigue Life of Additively Manufactured AlSi7Mg Alloy
}

\author{
Luiz Felipe Leitao Martins ${ }^{1,2} \mathbb{D}$, Paul R. Provencher ${ }^{1,2}$, Mathieu Brochu ${ }^{2,3}$ and Myriam Brochu ${ }^{1,2, *}$ \\ 1 Department of Mechanical Engineering, Polytechnique Montréal, Montreal, QC H3T 1J4, Canada; \\ luiz-felipe.leitao-martins@polymtl.ca (L.F.L.M.); paul.provencher@polymtl.ca (P.R.P.) \\ 2 Aluminium Research Centre-REGAL, Québec, QC G1V 0A6, Canada; mathieu.brochu@mcgill.ca \\ 3 Mining and Materials Engineering Department, McGill University, Montreal, QC H3A 0C5, Canada \\ * Correspondence: myriam.brochu@polymtl.ca; Tel.: +1-(514)-340-4711
}

Citation: Leitao Martins, L.F.;

Provencher, P.R.; Brochu, M.; Brochu,

M. Effect of Platform Temperature and Post-Processing Heat Treatment on the Fatigue Life of Additively Manufactured AlSi7Mg Alloy. Metals 2021, 11, 679. https://doi.org/ $10.3390 /$ met11050679

Academic Editor: Antonio Mateo

Received: 30 March 2021

Accepted: 19 April 2021

Published: 21 April 2021

Publisher's Note: MDPI stays neutral with regard to jurisdictional claims in published maps and institutional affiliations.

Copyright: (c) 2021 by the authors. Licensee MDPI, Basel, Switzerland. This article is an open access article distributed under the terms and conditions of the Creative Commons Attribution (CC BY) license (https:// creativecommons.org/licenses/by/ $4.0 /)$.

\begin{abstract}
The effect of platform temperature combined with a T5 heat treatment on the fatigue life of additively manufactured aluminum alloy AlSi7Mg was characterized and understood. Highcycle fatigue tests were carried out on samples built with four platform temperatures $\left(35^{\circ} \mathrm{C}, 60^{\circ} \mathrm{C}\right.$, $80^{\circ} \mathrm{C}$ and $200^{\circ} \mathrm{C}$ ) and post-processing heat treatment strategies (F and T5). Microstructural and fractographic observations combined with microhardness measurements were performed. A lognormal statistical distribution regressed with $90 \%$ B-basis probabilities of survival revealed that specimens produced on a platform maintained at $80^{\circ} \mathrm{C}$ and post-processed with a T5 heat treatment presented the highest fatigue life among the conditions tested. Precipitation of silicon within the aluminum cells during the T5 heat treatment is the proposed explanation for the improved fatigue life of the $\mathrm{T} 5$ samples. In the as-built condition, specimens produced at $200{ }^{\circ} \mathrm{C}$ were found to be less resistant to fatigue than the specimens built at lower temperatures. The coarser microstructure and lowest microhardness resulting from high-temperature manufacturing explain this reduced fatigue strength. All fatigue cracks initiated from manufacturing discontinuities. This led to a fatigue life prediction model based upon linear elastic fracture mechanics. The model was fitted to the experimental results of the $\mathrm{F}$ and $\mathrm{T} 5$ samples separately. With the exception of the $35{ }^{\circ} \mathrm{C}-\mathrm{T} 5$ specimens, the predicted fatigue lives agree with the experimental results and literature.
\end{abstract}

Keywords: additive manufacturing; AlSi7Mg alloy; platform temperature; aging; T5; fatigue life

\section{Introduction}

Selective laser melting (SLM) is the most adopted method of additive manufacturing (AM) for metals. This layer-by-layer process produces geometrically complex metal parts with minimal material waste. These characteristics make SLM attractive for several engineering applications, including for the aerospace industry. This sector imposes stringent design constraints to ensure reliability because the statistical spread of fatigue life is critical [1]. Stringent design for commercial and military aircraft structures and fastened joints drives the aeronautical and aerospace industries to use safety margins known as B-basis (90\% survival estimate with 95\% confidence) [2]. Hence, characterization and modeling of fatigue resistance of SLM built parts are central to the establishment of this technology in this industry.

Aluminum alloys are attractive in the transportation industry due to their high specific strength. SLM aluminum alloy parts with densities above $99 \%$ and fine microstructures have been successfully produced, although residual discontinuities, such as porosities and lack of fusion, are still observed [3-6]. Previous work has shown that these discontinuities strongly affect dynamic properties and fatigue behavior in particular [4,6-9].

Previous publications studied the mechanical properties of metallic SLM parts, including 316 stainless steel [10,11], Ti6Al4V [12-15], Inconel 718 [16] and aluminum alloys [3-9,17-28]. 
Siddique et al. [22] evaluated the influence of platform temperature on the microstructure, MONOTONIC and cyclic properties of AlSi12 samples. Samples produced without platform heating had dendrite width $\lambda=0.35 \mu \mathrm{m}$, compared to $\lambda=0.56 \mu \mathrm{m}$ for samples produced at $200{ }^{\circ} \mathrm{C}$ [22]. Specimens produced without platform heating and post-processing stressrelief treatment have the best fatigue performance, albeit with greater fatigue life scatter. For specimens produced with platform heating, coarse microstructure caused by slower cooling rates negatively impacted the mechanical strength and fatigue life. The mechanical properties of aluminum alloys were reported in several papers and for a variety of platform temperatures: $30^{\circ} \mathrm{C}[17], 35^{\circ} \mathrm{C}[4,26], 100{ }^{\circ} \mathrm{C}[27], 150{ }^{\circ} \mathrm{C}[28], 160{ }^{\circ} \mathrm{C}[18], 165^{\circ} \mathrm{C}[7,26]$, $180{ }^{\circ} \mathrm{C}[25], 200{ }^{\circ} \mathrm{C}[7,21,22]$ and $300{ }^{\circ} \mathrm{C}$ [17]. There is however limited data available on the fatigue properties of SLM parts manufactured from AlSi7Mg $[29,30]$ and nothing on the effect of platform temperature on mechanical properties for this specific alloy.

The microstructure and mechanical properties of AlSi7Mg and AlSi10Mg SLM parts precipitation hardened using a T6 heat treatment was recently studied $[17,18,24,31]$. Casati et al. [18] showed that the solution heat treatment suppresses the evidence of laser tracks and its related heat-affected zones. The fine Al cells surrounded by Si particles were replaced by a coarser grain structure and globular Si particles. Nevertheless, static mechanical properties, namely hardness, yield and ultimate strengths were reduced lower than the initial as-built levels [18]. To mitigate this deleterious effect of solution heat treatment, the response of AlSi7Mg SLM parts to T5 aging was investigated [18,19,31]. The data demonstrated that an ultimate tensile strength higher than that resulting from a $\mathrm{T} 6$ could be achieved. The $\mathrm{T} 5$ preserved the ultrafine Al cell structure while inducing the precipitation of strengthening phases [18]. Casati et al. [18] analyzed the effect of T5 treatment on aluminum specimens produced on platforms at room temperature (RT) and $160{ }^{\circ} \mathrm{C}$. They showed that higher hardness and tensile strengths were measured upon T5 aging of specimens produced at RT. It was explained that long periods spent at high temperature during the $\mathrm{AM}$ process induced overaging (i.e., an excessive aging period) in the samples produced at $160^{\circ} \mathrm{C}$. Therefore, hot platform processing can attenuate the aging response and reduce the monotonic mechanical properties.

These recent publications indicate that the fine SLM microstructure associated with a $\mathrm{T} 5$ post-processing treatment is responsible for an augmentation of the monotonic mechanical properties. Nevertheless, there is a knowledge gap on the influence of a combined effect of cold platform temperature and T5 post-processing on the fatigue life of additively manufactured AlSi7Mg alloy. Therefore, the goal of the present work is to understand how thermal strategies combining controlled platform temperatures and a T5 heat treatment could be profitable for dynamic properties.

For this purpose, polished specimens of AlSi7Mg alloy produced at $35{ }^{\circ} \mathrm{C}, 60{ }^{\circ} \mathrm{C}$, $80^{\circ} \mathrm{C}$ and $200^{\circ} \mathrm{C}$ were tested in rotating-bending fatigue (stress ratio $R=-1$ ) in $\mathrm{F}$ and $\mathrm{T} 5$ conditions with the intent of increasing the fatigue life in the high-cycle fatigue (HCF) regime. The scope was limited to material-process-treatment combinations that were not yet investigated by rotating-bending fatigue in order to provide original knowledge. Fatigue life results were analyzed using B-basis tolerance limits (95\% confidence level on the 90\% survival estimate) [1] to compare the lower bounds of the manufacturing conditions. Crackinitiating features were characterized in terms of nature, size and position. An estimation of the fatigue life based on the stress intensity factor at the crack-initiating discontinuities is proposed. The effect of the microstructure resulting from the different heat treatment conditions is discussed. Table A1 in Appendix A provides a list of nomenclature with symbols and abbreviations used in this document.

\section{Materials and Methods}

\subsection{Material}

The aluminum alloy investigated in this study is AlSi7Mg. This hypoeutectic alloy composition is close to the eutectic Al-Si composition, which is a class of alloys selected for good castability and solidification behavior among aluminum casting materials [17,20]. 
Minor additions of magnesium ( $0.3-0.5 \mathrm{wt} \%)$ allow age-hardenability by natural or artificial aging that raises strength by $\mathrm{Mg}_{2} \mathrm{Si}$ precipitation [19,32]. Table 1 shows the range of chemical compositions of all the batches of aluminum alloy used in this study. They all comply with the A357 alloy ASTM B108 [33] chemical requirements.

Table 1. Range of chemical composition in wt\% of the AlSi7Mg batches used and of the A357 alloy ASTM B108 [33] requirements.

\begin{tabular}{cccccccccc}
\hline $\mathbf{S i}$ & $\mathbf{M g}$ & $\mathbf{F e}$ & $\mathbf{C u}$ & $\mathbf{M n}$ & $\mathbf{T i}$ & $\mathbf{Z n}$ & Others & Al & Source \\
\hline $6.78-7.08$ & $0.58-0.67$ & $<0.12$ & $<0.01$ & $<0.01$ & $<0.10$ & $<0.01$ & $<0.15$ & Balance & Batches \\
$6.50-7.50$ & $0.40-0.70$ & $<0.20$ & $<0.20$ & $<0.10$ & $<0.10$ & $<0.10$ & $<0.15$ & Balance & A357 ASTM B108 \\
\hline
\end{tabular}

Samples were manufactured in an argon atmosphere with an EOS-brand machine operated with standard processing parameters as supplied by the manufacturer. The samples were manufactured using an AlSi7Mg powder composed of spherical particles with a particle size distribution ranging from 20 to $63 \mu \mathrm{m}$. Table 2 gives an overview of the manufacturing conditions and the number of specimens produced. The specimen blanks were printed in two main orientations ( $\mathrm{X}$ and $\mathrm{Z}$ build directions) as can be seen in Figure 1. Their dimensions are slightly larger (rectangular bar: length $90.2 \mathrm{~mm}$, width $10.3 \mathrm{~mm}$ and height $13.5 \mathrm{~mm}$; cylindrical bar: length $90.2 \mathrm{~mm}$ and diameter $10.3 \mathrm{~mm}$ ) than the fatigue specimen geometry presented in Figure 2. The thermal conditions considered in this investigation were selected with the intention of triggering the precipitation of silicon to increase fatigue properties. The samples were produced using different build platform temperatures: $35^{\circ} \mathrm{C}, 60{ }^{\circ} \mathrm{C}, 80^{\circ} \mathrm{C}$ (cold platforms) and $200{ }^{\circ} \mathrm{C}$ (hot platform). Half of the cold platform samples were aged with a T5 heat treatment at $160{ }^{\circ} \mathrm{C}$ for $6 \mathrm{~h}$. The cold platform temperatures were chosen to oversaturate the alpha phase with silicon and to minimize aging while manufacturing. On the other hand, the $200{ }^{\circ} \mathrm{C}$ platform temperature was intended to produce samples that would naturally age during AM processing. The samples produced at $200{ }^{\circ} \mathrm{C}$ were only tested in the as-built condition since further aging is unnecessary.

Table 2. Details of the batches of fatigue specimens.

\begin{tabular}{|c|c|c|c|c|c|}
\hline $\begin{array}{l}\text { Platform } \\
\text { Condition }\end{array}$ & $\begin{array}{c}\text { Batch } \\
\text { Number }\end{array}$ & $\begin{array}{c}\text { Platform } \\
\text { Temperature }\end{array}$ & $\begin{array}{c}\text { Build } \\
\text { Direction }\end{array}$ & $\begin{array}{l}\text { Thermal } \\
\text { Condition }\end{array}$ & $\begin{array}{l}\text { Number of } \\
\text { Specimens }\end{array}$ \\
\hline \multirow{2}{*}{ Hot platform } & \multirow{2}{*}{$\# 1$} & \multirow{2}{*}{$200^{\circ} \mathrm{C}$} & $x$ & F (as-built) & 15 \\
\hline & & & Z & F (as-built) & 15 \\
\hline \multirow{12}{*}{$\begin{array}{c}\text { Cold } \\
\text { platforms }\end{array}$} & \multirow{4}{*}{$\# 2$} & \multirow{4}{*}{$35^{\circ} \mathrm{C}$} & $x$ & F (as-built) & 6 \\
\hline & & & $\mathrm{Z}$ & F (as-built) & 6 \\
\hline & & & $X$ & T5 & 7 \\
\hline & & & Z & T5 & 7 \\
\hline & \multirow{4}{*}{$\# 3$} & \multirow{4}{*}{$60^{\circ} \mathrm{C}$} & $x$ & F (as-built) & 6 \\
\hline & & & $\mathrm{Z}$ & F (as-built) & 6 \\
\hline & & & $x$ & T5 & 7 \\
\hline & & & $\mathrm{Z}$ & T5 & 7 \\
\hline & \multirow{4}{*}{$\# 4$} & \multirow{4}{*}{$80^{\circ} \mathrm{C}$} & $x$ & F (as-built) & 6 \\
\hline & & & $\mathrm{Z}$ & F (as-built) & 6 \\
\hline & & & $x$ & T5 & 7 \\
\hline & & & Z & T5 & 7 \\
\hline
\end{tabular}




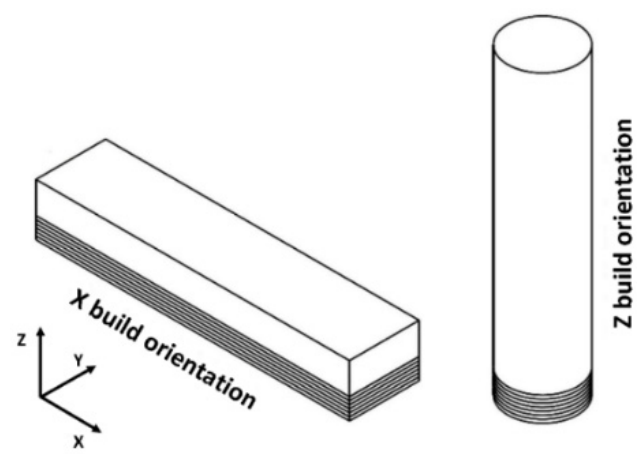

Figure 1. Representation of the build orientations of the samples and the blank geometries. The first layers of the SLM process are depicted. The drawings are not to scale.

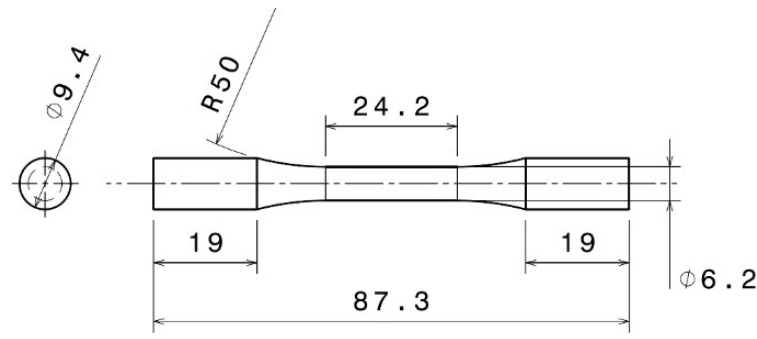

General Tolerances: $+/-0.25$

(a)

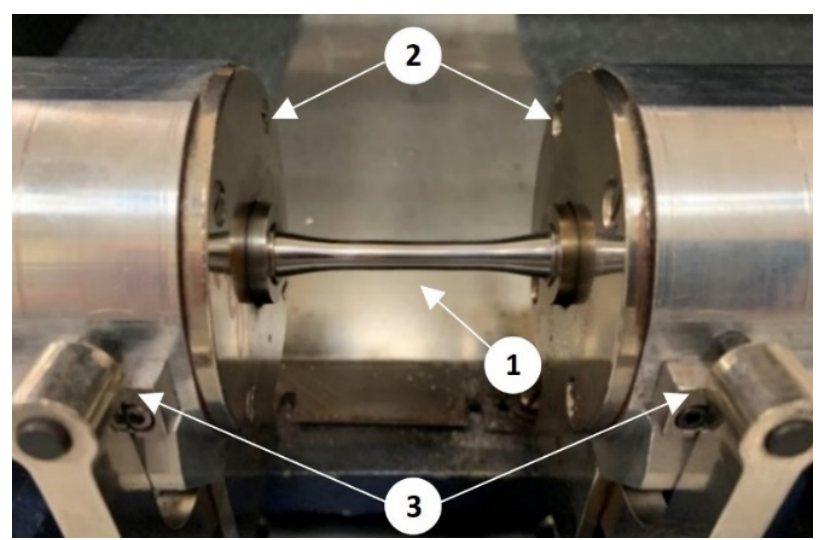

(b)

Figure 2. Experimental setup. (a) Fatigue test specimen design, dimensions in mm. (b) Experimental assembly: (1) polished specimen, (2) bearing shafts, (3) load-bearing system.

Samples were cut from the build plate by electrical discharge machining (EDM) and were then machined to the final geometry presented in Figure 2, in accordance with ASTM E466 design specifications [34]. The gauge surfaces were polished to below a $3 \mu \mathrm{m}$ finish (mirror condition) using progressively finer grades of $\mathrm{SiC}$ followed by treatment with diamond suspensions. Figure $2 \mathrm{~b}$ shows the experimental assembly, composed of a polished specimen, two bearing shafts and a load-bearing system.

\subsection{Characterization}

Microstructural characterization was performed by observing polished and etched samples. Vertical and horizontal cross-sections of the samples were ground and polished to a mirror finish with a manual polishing machine. The samples were polished using progressively finer grades of $\mathrm{SiC}$ paper followed by cloth polishing with diamond suspensions and a $0.05 \mu \mathrm{m}$ colloidal silica suspension. Etching was then performed for $10 \mathrm{~s}$ using a solution of $10 \%$ vol. $\mathrm{HF}$ and $90 \%$ vol. $\mathrm{H}_{2} \mathrm{O}$. Microstructural characterization and fracture surfaces were examined using a digital microscope and a scanning electron microscope (SEM).

Vickers microhardness was measured on the polished surfaces by 5 indentations under a load of $100 \mathrm{gf}$ applied for $10 \mathrm{~s}$. High-cycle fatigue (HCF) tests were conducted in rotating-bending fatigue (stress ratio $R=-1$ ) at $40 \mathrm{~Hz}$, in accordance with ISO 1143 [35]. The stress amplitude $\sigma_{a}$ for cylindrical specimens was estimated as $\sigma_{a}=16 \mathrm{WL} / \pi D^{3}$, where $W$ is the load in $\mathrm{N}, L$ is the length in $\mathrm{mm}$ and $D$ the sample diameter in $\mathrm{mm}$. For each batch of material, the stress amplitude was selected to aim for an average fatigue life of $10^{6}$ cycles. To minimize the number of specimens wasted to reach the targeted fatigue life, the first sample was tested at $110 \mathrm{MPa}$ and increments of $5 \mathrm{MPa}$ were applied 
when reaching $5 \times 10^{6}$ cycles without failure. The stress level that led to failure after $5 \times 10^{6}$ cycles or shorter was chosen to test the remaining samples of a given batch. Based on this methodology, the stress amplitude was $130 \mathrm{MPa}$ for batch \#1 and $135 \mathrm{MPa}$ for batches \#2, \#3 and \#4.

\subsection{Probabilistic Analysis}

The statistical distribution that best described the data was identified with the AndersonDarling goodness-of-fit coefficient of determination $\left(R^{2}\right)$ [36]. The models considered were the generalized extreme value (GEV), log-normal, normal and Weibull distributions. The log-normal distribution, frequently used to characterize fatigue life data of polished samples $[37,38]$, best fit the majority of the results as expanded upon in Section 3.3. The probability density function $f^{\log -\text { normal }}(x)$ for a random variable $x$ following the log-normal distribution is given by:

$$
f^{\log -\operatorname{normal}}(x)=\frac{1}{x} \frac{1}{\sigma \sqrt{2 \pi}} \exp \left(-\frac{(\log (x-\mu))^{2}}{2 \sigma^{2}}\right)
$$

where $\mu$ (the mean) is the shape and $\sigma$ (the standard variation) is the scale parameter of the natural logarithm function. This model was used for the B-basis evaluation. The B-basis value, adopted by the aerospace industry [1], is defined as a statistical prediction of the lower bound for $90 \%$ survival rate with $95 \%$ confidence level (on the conservative side) [1].

\subsection{Fatigue Life Prediction}

A crack propagation model correlating the defect area projected on the fracture surface and the fatigue life was used. The quantity $\sqrt{ }$ area defined by Murakami [39] produces good correlation for several metals between the fatigue life and the crack initiating feature. It was originally proposed to explain the effect of the size and location of small inclusions on the fatigue life of rotation-bending fatigue specimens manufactured from steel. In the case of a single defect, the area of a defect is given by the area of the convex shape contouring the defect projected on the fracture plane. In the event of a defect at the sub-surface, for $a / d>0.8$, where $a$ is the ratio of the crack radius and $d$ is the distance from the specimen surface to the center of the defect, the area of the contour is extended to include the area of the ligament between the defect and the free surface.

Quantitative relationships between defect area and fatigue life have been studied for cast Al-Si alloys, particularly for A356 $[40,41]$. The integration of Paris' equation, in which the initial crack length was replaced by the $\sqrt{ }$ area of the crack initiating defect resulted in a fair estimation of fatigue lives in the work of Saberifar et al. [42]. This approach was used to analyze the results reported in the present paper.

\section{Results}

\subsection{Microstructure}

The microstructure was characterized as a function of four main characteristics: (1) melt-pools, (2) aluminum dendritic structure, (3) presence of silicon precipitates and (4) porosity. Images of F and T5 microstructure were taken for all manufacturing conditions. Figure 3 shows representative images of the top and the side of as-built microstructure of samples produced at $200^{\circ} \mathrm{C}$. 


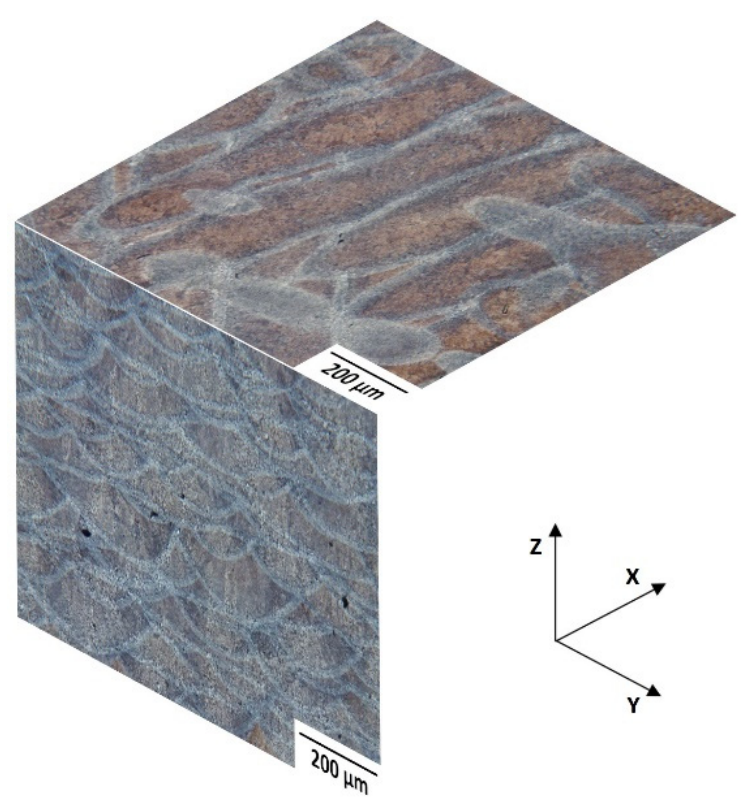

(a)

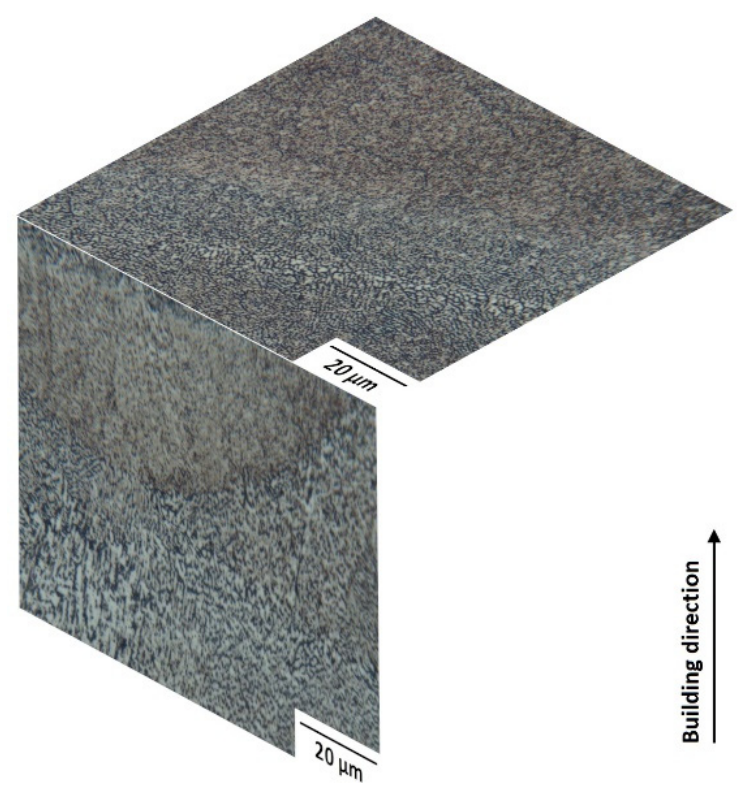

(b)

Figure 3. Typical microstructure of the AlSi7Mg Z-built parts produced by SLM on the hot platform at $200{ }^{\circ} \mathrm{C} ;($ a) $100 \times$ and (b) $1000 \times$ magnifications.

\subsubsection{Meltpools}

Similarly to previous works $[23,24]$, it is possible to see the laser traces made up of solidifications tracks of the melt-pools, especially from side views (parallel to the building direction). There was no difference in melt pool size from one batch to another, as seen by comparing the images in Figure 4 showing the typical microstructures of as-built samples produced at $35{ }^{\circ} \mathrm{C}, 60{ }^{\circ} \mathrm{C}, 80^{\circ} \mathrm{C}$ and $200{ }^{\circ} \mathrm{C}$. These half-cylindrical molten pools were $176 \pm 26 \mu \mathrm{m}$ wide and $57 \pm 7 \mu \mathrm{m}$ high.

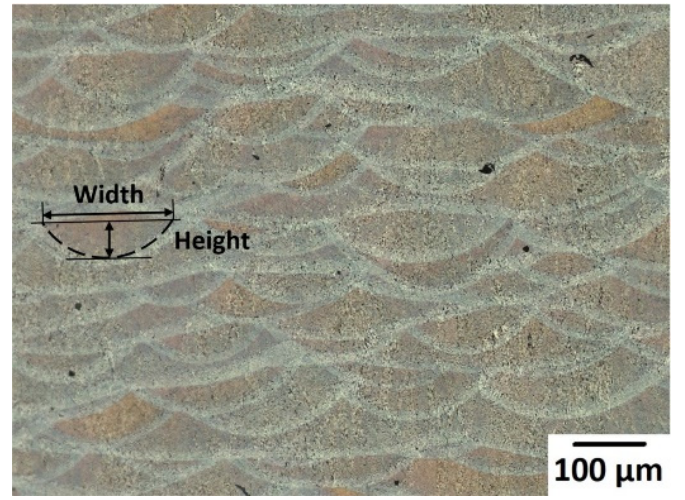

(a)

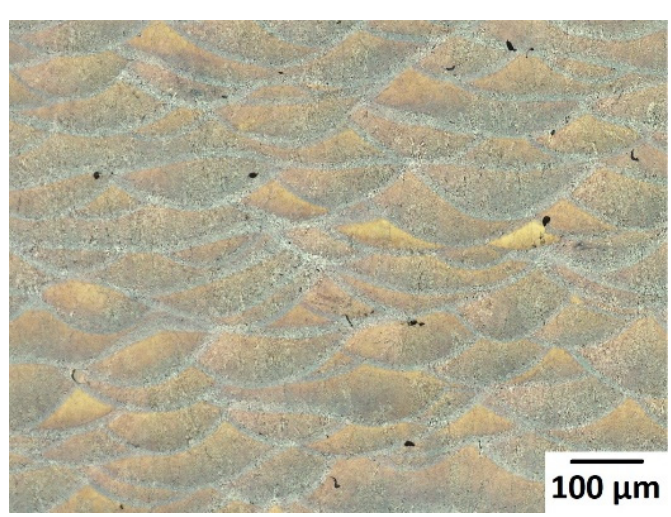

(b)

Figure 4. Cont. 


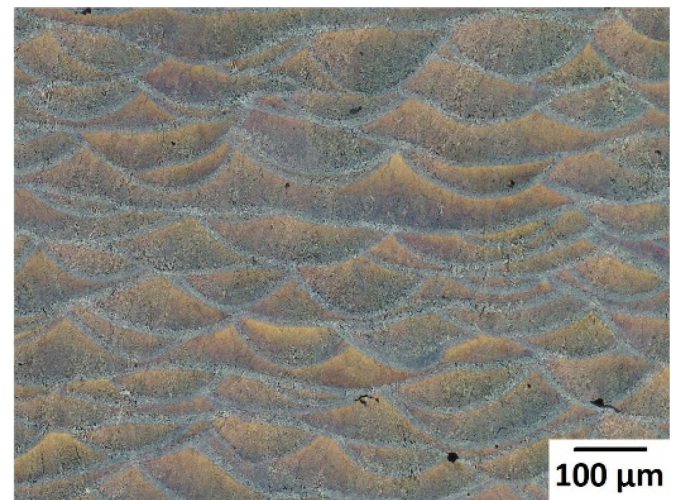

(c)

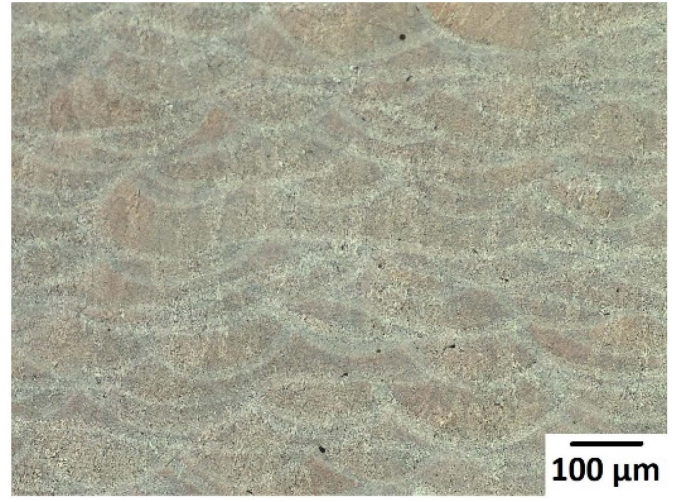

(d)

Figure 4. Typical melt-pool microstructure of the AlSi7Mg X-built parts produced by SLM at: (a) $35{ }^{\circ} \mathrm{C},(\mathbf{b}) 60^{\circ} \mathrm{C},(\mathbf{c}) 80^{\circ} \mathrm{C}$ and (d) $200^{\circ} \mathrm{C} ; 200 \times$ magnification. Width and height measurements of an individual melt pool are annotated in (a). The build direction is vertical gravitationally and upwards on the page.

\subsubsection{Dendritic Structure}

The microstructure inside a melt pool is composed of an $\mathrm{Al}$ matrix and Si particles. The dendritic structure, shown in Figure 5, was characterized by the size of the Al matrix surrounded by Si, called dendritic arm spacing (DAS) [9] or simply dendritic width [22]. The fast SLM solidification hinders the formation of secondary arms seen in the common cast aluminum structures [9]. Therefore, dendrites have a cellular shape on the plane normal to the building direction. SEM observations at $5000 \times$ were used to measure DAS. The average DAS was measured by 50 intercepts on planes parallel to the building direction by the intercept method, following ASTM E112 recommendations [43]. Dendritic microstructural measurements of samples fabricated in the $X$ direction are summarized in Table 3.

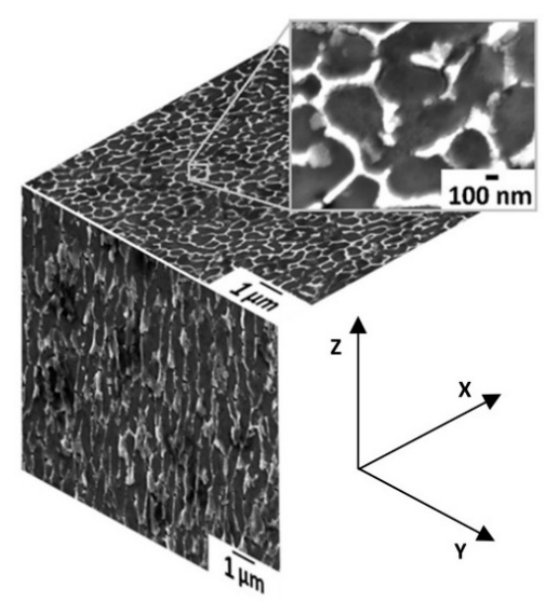

(a)

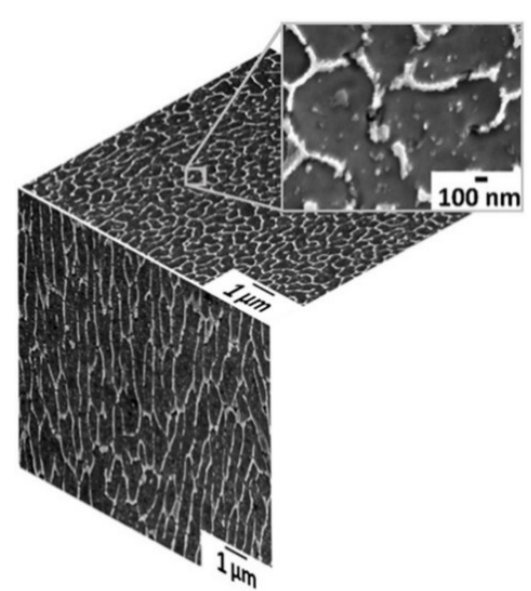

(b)

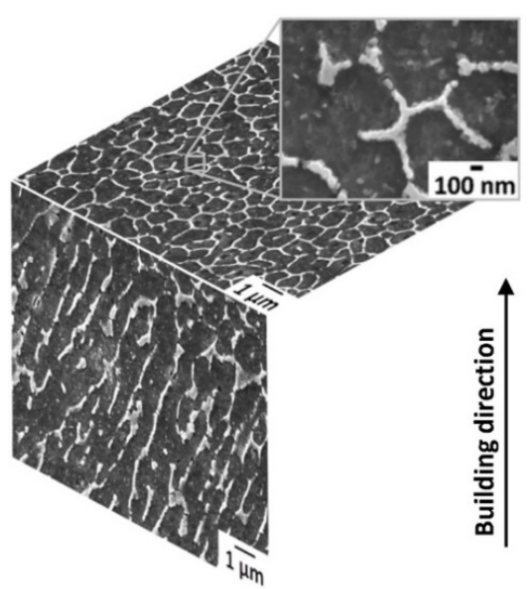

(c)

Figure 5. High-magnification SEM images $(10,000 \times$ and $50,000 \times)$ of the typical microstructure at $35{ }^{\circ} \mathrm{C} \mathrm{F}(\mathbf{a})$, T5 (b) and $200{ }^{\circ} \mathrm{C} \mathrm{F}$ (c) build conditions. The $\mathrm{Al}$ matrix is the dark phase and the lighter phase surrounding the $\mathrm{Al}$ matrix is Si particles. In $(\mathbf{b}, \mathbf{c})$, discrete Si precipitations were observed from thermal heat treatment. 
Table 3. Average dendritic width parameter of AlSi7Mg batches.

\begin{tabular}{ccccc}
\hline $\begin{array}{c}\text { Platform } \\
\text { Condition }\end{array}$ & Batch Number & $\begin{array}{c}\text { Platform } \\
\text { Temperature }\end{array}$ & $\begin{array}{c}\text { Thermal } \\
\text { Condition }\end{array}$ & $\begin{array}{c}\text { Dendritic } \\
\text { Width, } \lambda(\mu \mathrm{m})\end{array}$ \\
\hline Hot platform & $\# 1$ & $200{ }^{\circ} \mathrm{C}$ & $\mathrm{F}$ & $0.64 \pm 0.04$ \\
\hline \multirow{3}{*}{ Cold platforms } & $\# 2$ & $35{ }^{\circ} \mathrm{C}$ & $\mathrm{F}$ & $0.45 \pm 0.01$ \\
& \multirow{2}{*}{$\# 3$} & \multirow{2}{*}{$60^{\circ} \mathrm{C}$} & $\mathrm{T} 5$ & $0.43 \pm 0.01$ \\
\cline { 2 - 5 } & \multirow{2}{*}{$\# 4$} & $\mathrm{~F}$ & $0.46 \pm 0.01$ \\
& \multirow{2}{*}{$80^{\circ} \mathrm{C}$} & $\mathrm{T} 5$ & $0.43 \pm 0.01$ \\
\hline
\end{tabular}

Values published by Siddique et al. [22] were slightly smaller to those in the present work. Siddique et al. found DAS equal to $\lambda=0.35 \mu \mathrm{m}$ for samples produced without platform heating and $\lambda=0.56 \mu \mathrm{m}$ for samples produced on a platform temperature of $200{ }^{\circ} \mathrm{C}$. This difference with our results could be explained by a difference in the specific process parameters used for sample manufacturing. However, in agreement with previous publications, the average DAS ranges between $0.43 \mu \mathrm{m}$ and $0.64 \mu \mathrm{m}$ with larger DAS for samples produced on heated platforms. Differences in dendritic width are attributed to difference in cooling rates as influenced by the platform heating. Cold platform resulted in higher cooling rates leading to a finer dendritic structure [22].

For the batches built at temperatures of $35^{\circ} \mathrm{C}, 60^{\circ} \mathrm{C}$ and $80^{\circ} \mathrm{C}$, no significant difference was observed in dendrite width. As expected, the T5 heat treatment did not modify the size of the DAS as shown by the results in Table 3.

\subsubsection{Silicon Precipitation}

High-magnification SEM observations revealed microstructural differences between hot and cold platform samples and between as-built and T5 conditions. The Si walls looked continuous and thicker in the microstructure of the cold platform samples, while they were thinner and interrupted for the samples produced at $200{ }^{\circ} \mathrm{C}$ (see Figure 5). In addition, silicon precipitation was observed inside the dendrites in the latter sample. All samples heat treated T5 had a silicon distribution comparable to the samples produced at $200^{\circ} \mathrm{C}$ : thin discontinuous silicon walls and silicon precipitation inside the dendrites. This is in good agreement with the results published by Casati et al. [18], who investigated the effect of heating the build platform to $160^{\circ} \mathrm{C}$ on the solidification microstructure of AlSi10Mg alloy. For specimens built at $160^{\circ} \mathrm{C}$, the holding period at high temperature led to the precipitation of $\mathrm{Si}$ particles within the aluminum matrix.

\subsubsection{Porosity}

Examples of pores visible under optical microscopy at a magnification of $500 \times$ are presented in Figure 6a. The size distributions of these discontinuities (larger than $10 \mu \mathrm{m}$ ) observed on $25 \mathrm{~mm}^{2}$ over cross sections of each batch of material are shown in Figure 7. The distributions show comparable size ranges and counts within all batches. The larger discontinuities observed are lack of fusion (LoF), as shown in Figure 6b. Those LoF were mainly located at or close to the molten pool boundaries. Their elongated shape results in a larger projected area on a plane normal to the building direction. Therefore, it can be anticipated that these features will be more deleterious when load is applied parallel to the building direction (specimens referred to as Z). 


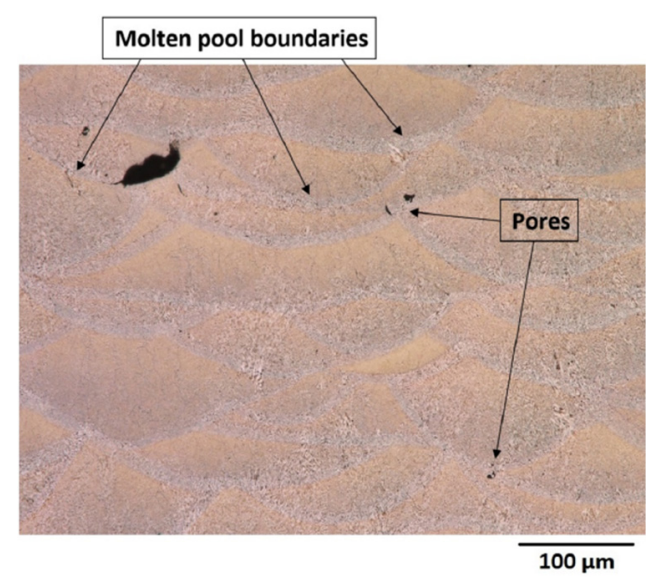

(a)

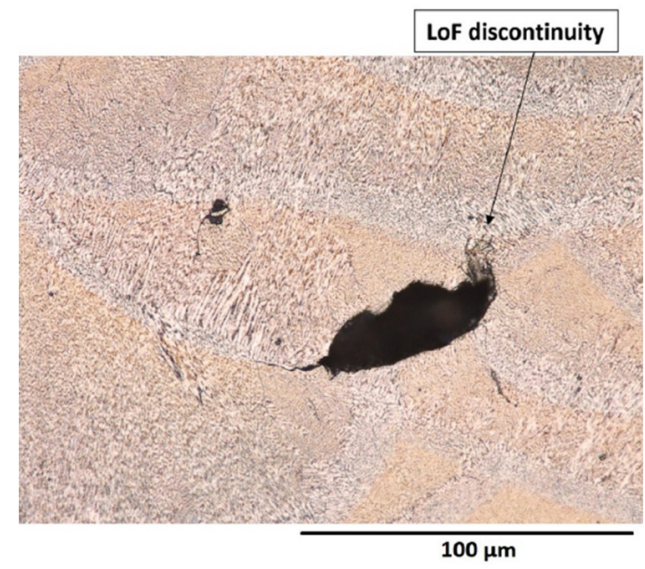

(b)

Figure 6. Optical micrograph of lack of fusion $(\mathrm{LoF})$ representative discontinuity; (a) $500 \times$ and (b) $1500 \times$ magnifications.

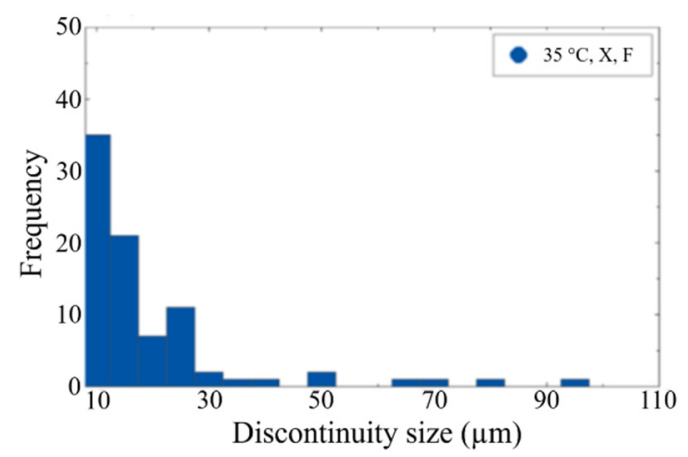

(a)

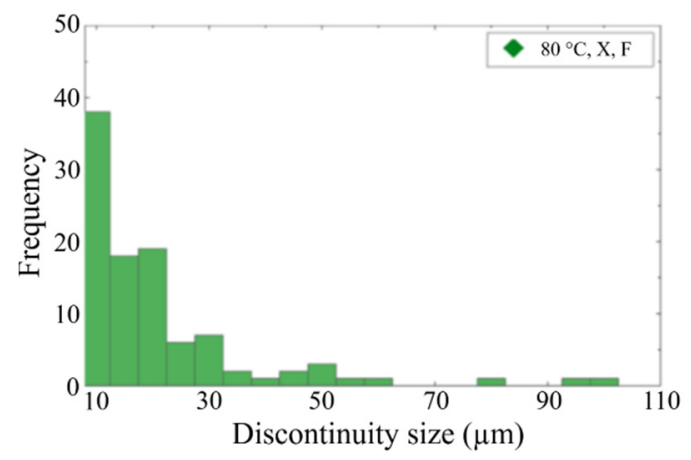

(c)

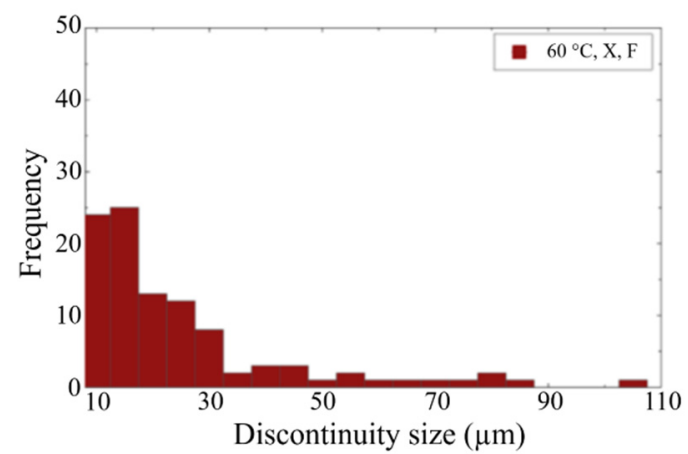

(b)

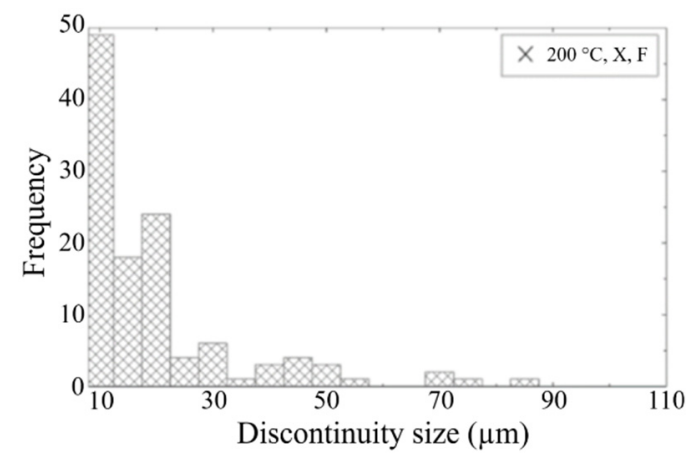

(d)

Figure 7. Histograms of porosity size of AlSi7Mg X as-built parts produced by SLM at $35^{\circ} \mathrm{C}(\mathbf{a}), 60^{\circ} \mathrm{C}(\mathbf{b}) 80^{\circ} \mathrm{C}(\mathbf{c})$ and $200{ }^{\circ} \mathrm{C}(\mathbf{d})$.

\subsection{Vickers Hardness}

The average Vickers hardness (HV) measurements of the different as-built samples are reported as the filled symbols in Figure 8. The values of $X$ and Z-built samples are not significantly different as seen by comparing the graphs on Figure $8 \mathrm{a}$,b. Theoretically, for samples produced on a hot platform, a lower hardness is expected since the resulting cooling rate of the fused metal is lower, which resulted in a coarser microstructure [18]. This trend was only evident for the samples produced at $200^{\circ} \mathrm{C}$, which have an average microhardness of about $99 \mathrm{HV}$ compared to the averages of $117 \mathrm{HV}, 124 \mathrm{HV}$ and $122 \mathrm{HV}$ measured on the as-built (F) samples produced at $35^{\circ} \mathrm{C}, 60^{\circ} \mathrm{C}$ and $80^{\circ} \mathrm{C}$, respectively. This is coherent with the microstructural observations showing no significant different in the 
DAS between the 3 batches of material produced on the cold platform $\left(35^{\circ} \mathrm{C}, 60{ }^{\circ} \mathrm{C}\right.$ and $80^{\circ} \mathrm{C}$ ) but a larger DAS for the samples produced at $200^{\circ} \mathrm{C}$ (the DAS values are reported in Table 3).

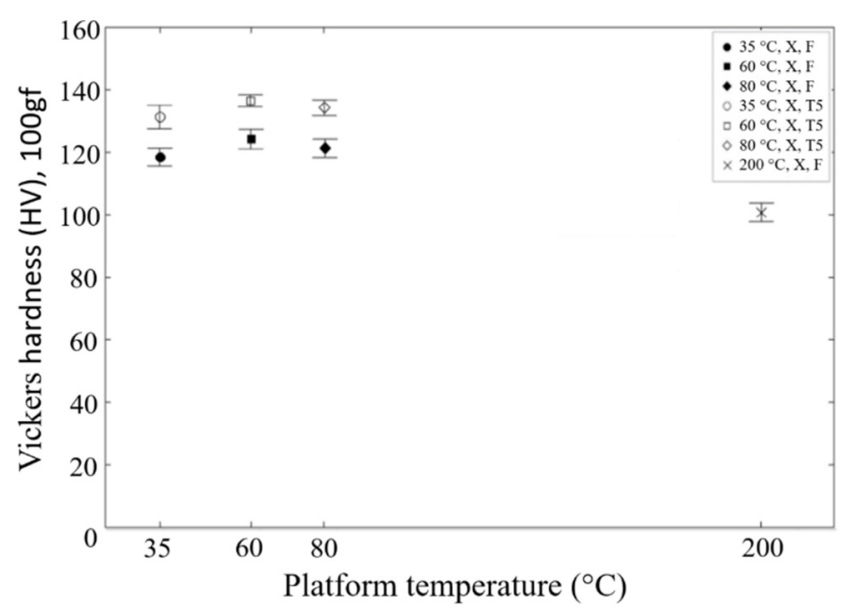

(a)

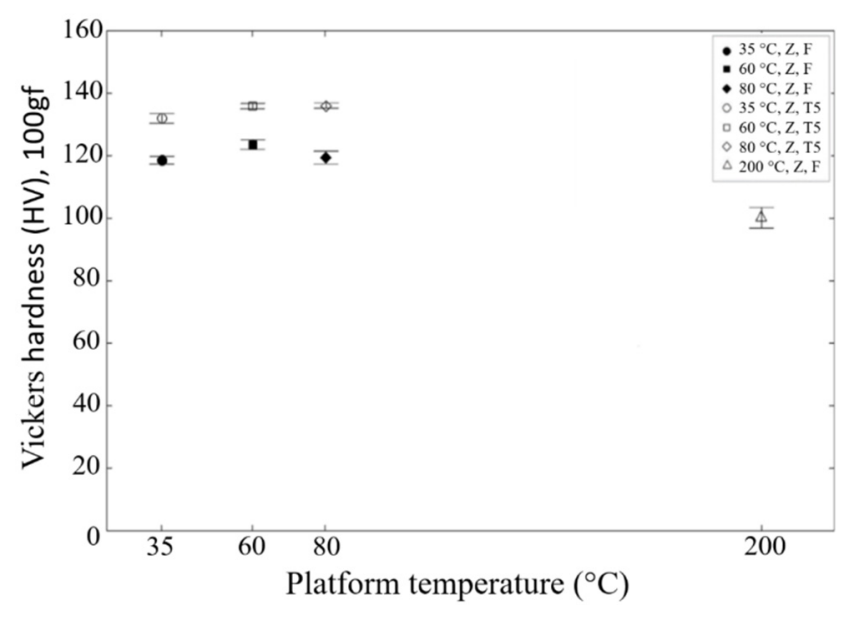

(b)

Figure 8. Vickers hardness of X-built (a) and Z-built (b) batches, HV 100 gf.

The effect of the T5 heat treatment on hardness can be observed by comparing the filled and empty symbols presented in Figure 8. The artificial aging led to increased hardness compared to as-built (F) samples. This could be anticipated from the microstructure investigation that shows no microstructural coarsening but a precipitation of $\mathrm{Si}$ within the dendrite structure (the microstructures were presented in Figure 5). This is coherent with Casati et al. [18] who showed that samples produced on cold platforms could be directly hardened from the as built condition. In addition, $\mathrm{Mg}_{2} \mathrm{Si}$ precipitates, not visible under SEM, may have contributed to this hardening, as proposed in the work of Siddique et al. performed on a comparable alloy manufacturer and heat treated in comparable conditions [22].

\subsection{Fatigue Test Results and Probabilistic Analysis}

Figures 9 and 10 show fatigue data, obtained by rotating-bending fatigue tests $(R=-1)$, at stress amplitudes of $135 \mathrm{MPa}$ for the specimens manufactured on cold platforms and at $130 \mathrm{MPa}$ for the platform preheated at $200{ }^{\circ} \mathrm{C}$. The number of cycles to failure $\left(N_{f}\right)$ is displayed on the abscissa for the corresponding SLM conditions reported as categories on the vertical axis.

Table A2 provides the coefficient of determination $\left(R^{2}\right)$ for 4 statistical distributions investigated to fit the results. The coefficient of determination is greatest for the log-normal distribution for 11 series of fatigue tests out of 14 , motivating the choice of working with log-normal distribution for the B-basis analysis. Figures 11 and 12 present probability density functions of log-normal distributions (Equation (1)) fitted to the experimental outcome reported in the form of percentage of failed specimens, within a given series, as a function of the number of load cycles. Table $\mathrm{A} 3$ presents the regression parameters of these log-normal distributions from which the average fatigue lives and B-basis values for a $90 \%$ probability of survival were calculated. 


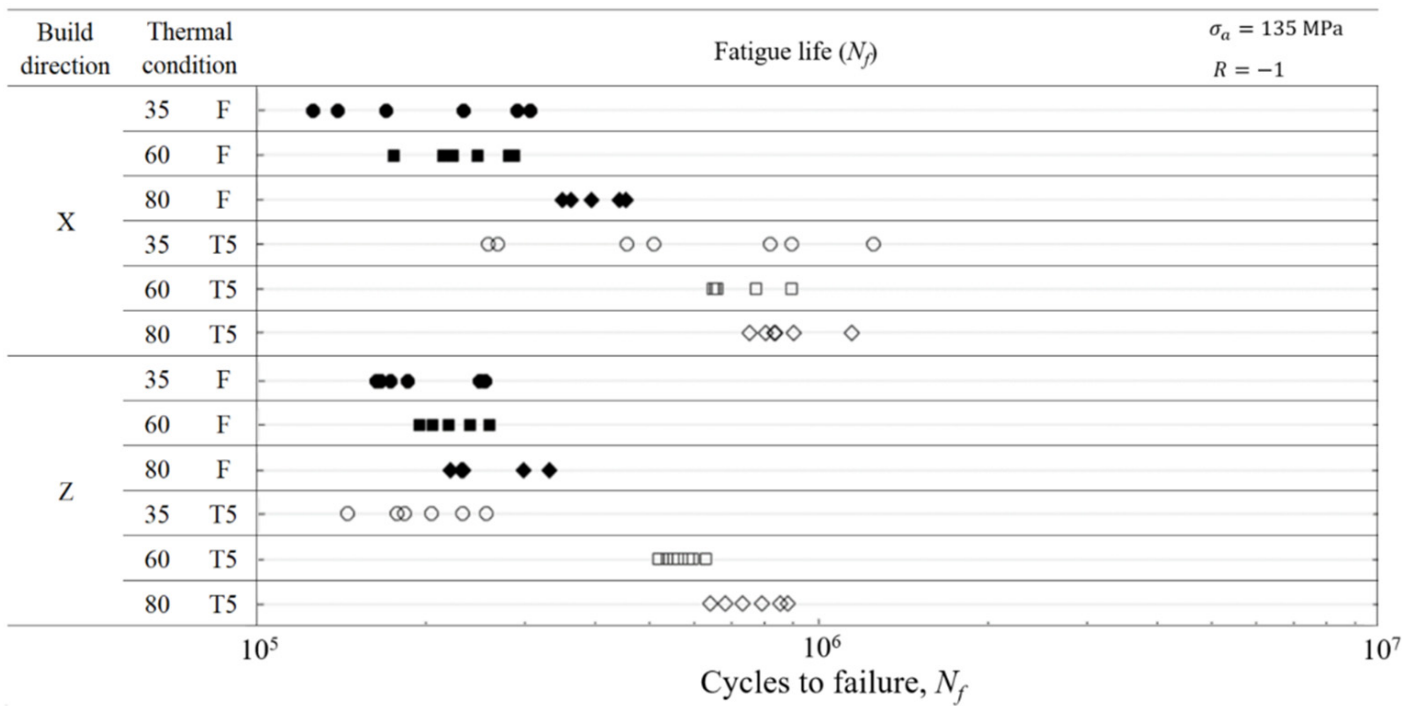

Figure 9. Fatigue life from rotating-bending fatigue tests at $135 \mathrm{MPa}$ for $35{ }^{\circ} \mathrm{C}, 60{ }^{\circ} \mathrm{C}$ and $80{ }^{\circ} \mathrm{C}$ conditions $(\mathrm{X}$ and $\mathrm{Z}$ building conditions).

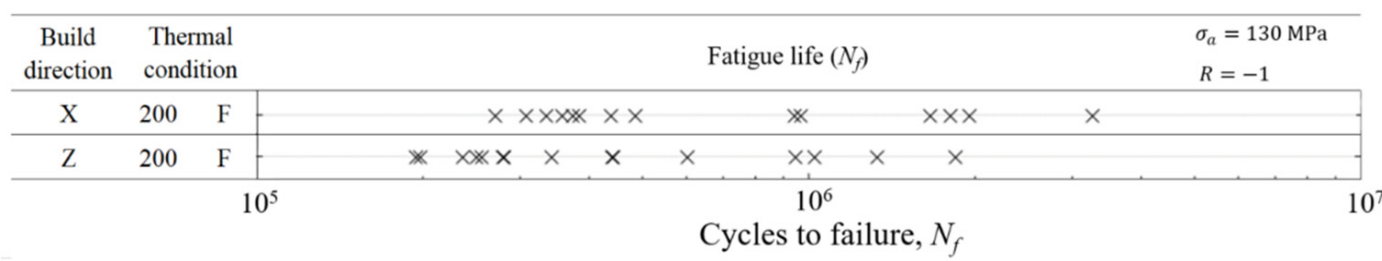

Figure 10. Fatigue life from rotating-bending fatigue tests at $130 \mathrm{MPa}$ for $200{ }^{\circ} \mathrm{C}$ condition (X and $\mathrm{Z}$ building conditions).

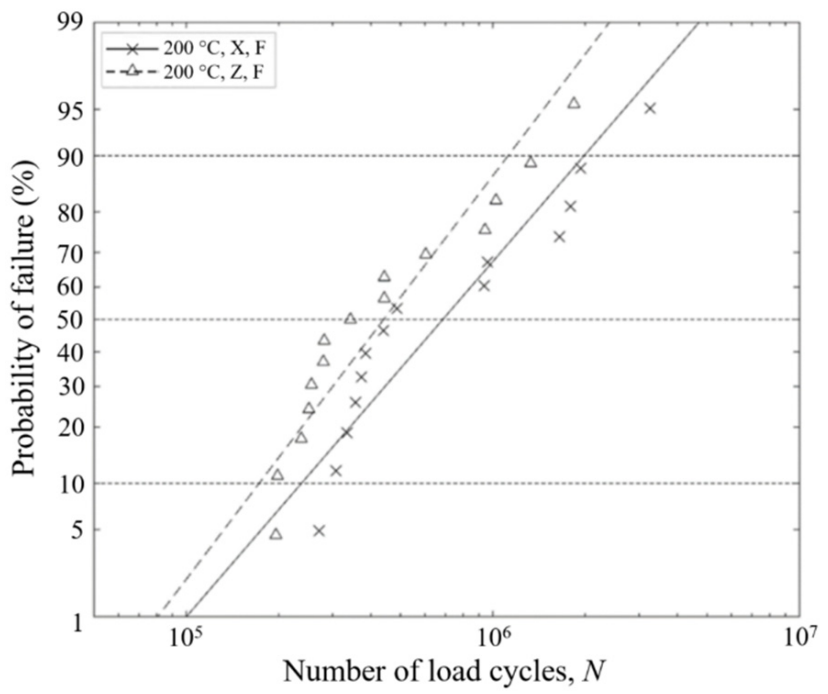

Figure 11. Probability of failure (\%) vs. number of load cycles, $N$. The probability density function of log-normal distributions is fitted to each series of experimental results. The stress amplitude was $130 \mathrm{MPa}$ for the $200{ }^{\circ} \mathrm{C}, \mathrm{X}$ and $\mathrm{Z}$ building conditions. 


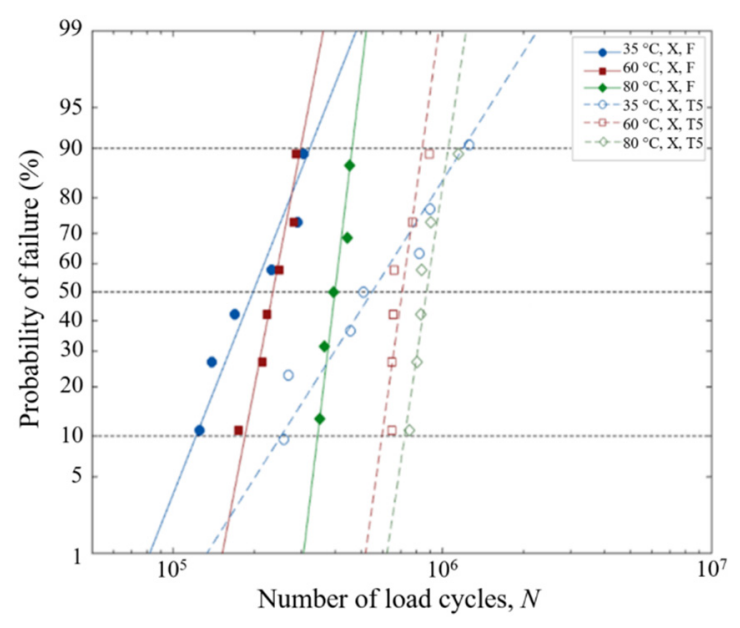

(a)

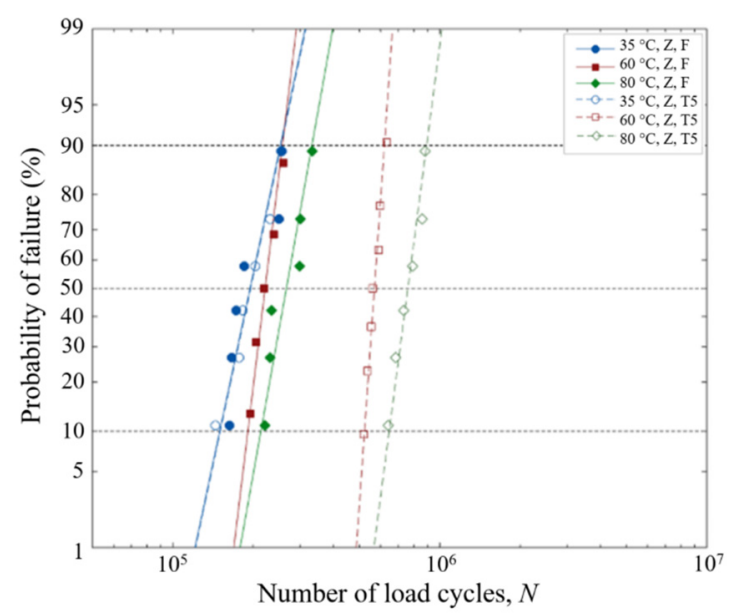

(b)

Figure 12. Probability of failure (\%) vs. number of load cycles, $N$. The probability density function of log-normal distributions is fitted to each series of experimental results. The stress amplitude was $135 \mathrm{MPa}$ for the $35^{\circ} \mathrm{C}, 60^{\circ} \mathrm{C}$ and $80{ }^{\circ} \mathrm{C}, \mathrm{X}(\mathbf{a})$ and $\mathrm{Z}$ (b) building conditions.

According to the average fatigue lives reported in Table A3, for all AM conditions, $\mathrm{X}$-built specimens sustained longer fatigue lives than $\mathrm{Z}$ specimens. As observed from the presented results and in accordance with previously mentioned studies [23], Z-built specimens tended to have shorter fatigue lives. The elongated shape of the largest discontinuities (LoF) as commented in Section 3.1.4 could be responsible for reducing the life of specimens tested with the load parallel to the build direction. Comparing the specimens produced at $200{ }^{\circ} \mathrm{C}$, the average fatigue life obtained from the $\mathrm{X}$-built condition $\left(9.63 \times 10^{5}\right.$ cycles) was 1.67 times longer than the Z-built condition $\left(5.77 \times 10^{5}\right.$ cycles), although the greater statistical scatter was observed for the X-built condition. The B-basis value for the $\mathrm{X}$-built condition $\left(2.34 \times 10^{5}\right.$ cycles) was only 1.38 times higher than the Z-built condition $\left(1.69 \times 10^{5}\right.$ cycles $)$.

Nevertheless, the statistical scatter was generally greater for the X-built condition, with the exception of the as-built specimens produced at $80^{\circ} \mathrm{C}$. This difference in scatter between $X$ and $Z$ results caused the $90 \%$ probability of survival to be smaller for two batches of $X$ specimens when compared to the $Z$ specimens (as-built conditions produced at $35^{\circ} \mathrm{C}$ and $60^{\circ} \mathrm{C}$ ). This is a marginal trend that could be reversed if a larger number of samples were tested.

Comparing the average fatigue lives of samples produced on cold platforms in the asbuilt conditions $\left(35^{\circ} \mathrm{C}, 60^{\circ} \mathrm{C}\right.$ and $80^{\circ} \mathrm{C}$ ), the highest average was found for the specimens produced at $80^{\circ} \mathrm{C}\left(4.03 \times 10^{5}\right.$ cycles for X-built specimens and $2.71 \times 10^{5}$ cycles for Zbuilt specimens), while the lowest average for the specimens produced at $35^{\circ} \mathrm{CX}$ and $\mathrm{Z}$ conditions $\left(2.16 \times 10^{5}\right.$ cycles for X-built specimens and $1.99 \times 10^{5}$ cycles for Z-built specimens). The same trend was observed when comparing the B-basis values with the highest characterizing the specimens produced at $80^{\circ} \mathrm{C}\left(3.39 \times 10^{5}\right.$ cycles for X-built specimens and $2.11 \times 10^{5}$ cycles for Z-built specimens), and the lowest for the $35{ }^{\circ} \mathrm{C}$ conditions $\left(1.16 \times 10^{5}\right.$ cycles for X-built specimens and $1.48 \times 10^{5}$ cycles for Z-built specimens). In this range of cold platform temperature, the results showed a trend of longer fatigue lives for warmer conditions. Nevertheless, this trend is blended with the scatter of the results. For example, the cold platform sample that sustained the highest number of load cycles was built on a $35{ }^{\circ} \mathrm{C}$ (not the warmest one).

When comparing as-built (F) and artificially aged (T5) specimens, the highest average and B-basis fatigue lives were systematically obtained for the batches of aged specimens. There is only one exception to this observation. In the Z-built condition, the samples produced at $35^{\circ} \mathrm{C}$ sustained $1.46 \times 10^{5}$ cycles against $1.48 \times 10^{5}$ cycles for the as-built condition, but this difference is insignificant. Microstructural observations presented in 
Section 3.1.3. can be used to explain the difference between F and T5 samples. The T5 heat treatment resulted in the precipitation of Si particles, which may act as microstructural barriers to the mobility of dislocations, benefitting fatigue by delaying the accumulation of plastic damage. Finally, when analyzing the effects of sample orientation, platform temperature and $\mathrm{T} 5$ heat treatment, the $\mathrm{T} 5$ aged specimens built in the $\mathrm{X}$ direction at $80^{\circ} \mathrm{C}$ sustained the highest number of load cycles for a $90 \%$ probability of survival. This is 1.20 and 3.08 times the number of cycles of that the $\mathrm{T} 5$ specimens built in the $\mathrm{X}$ direction at $60{ }^{\circ} \mathrm{C}$ and $35^{\circ} \mathrm{C}$, respectively.

Figure 13 presents a comparison of our results with those published by Beevers et al. [26] (SLM built at $165{ }^{\circ} \mathrm{C}-\mathrm{F}$ ), Mower et al. [21] (SLM built at $200{ }^{\circ} \mathrm{C}-\mathrm{SR}$, stress relief), and Brochu et al. [44] (permanent mold (PM)-F; PM-T6; semi-solid molding (SSM)-F; SSM-T5). The fatigue behavior of the specimens produced in this work falls in the range of the results reported by Mower et al. [21] and Beevers et al. [26] for AlSi10Mg additively manufactured alloy. It is also consistent with the fatigue strength reported for conventional and semi-solid 357 cast alloy studied by Brochu et al. [44].

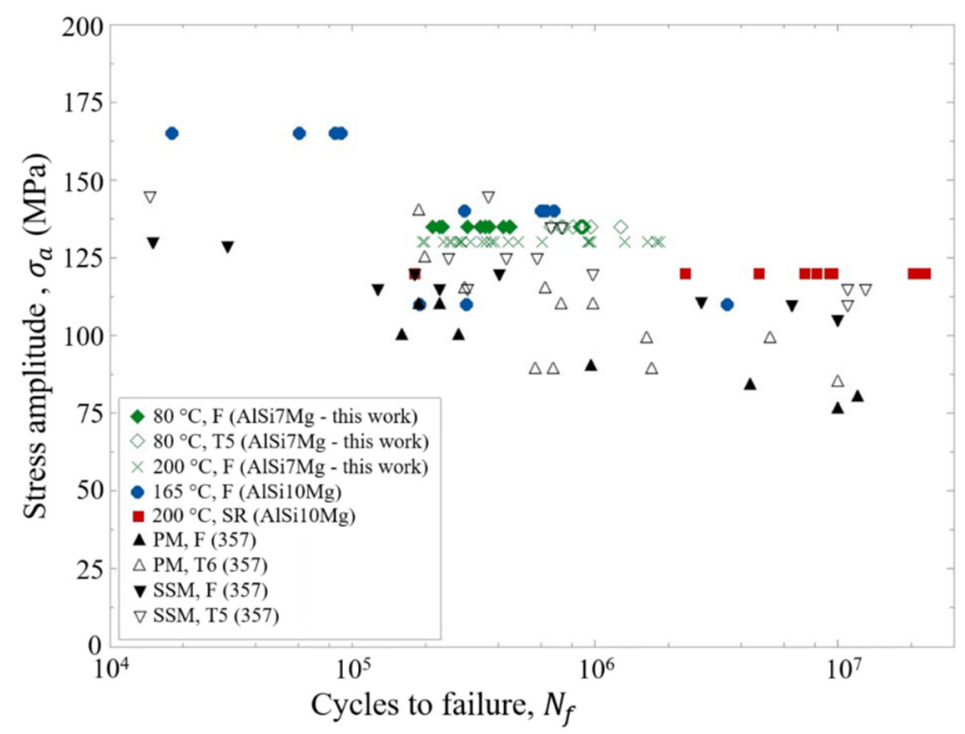

Figure 13. Fatigue behavior of AlSi7Mg specimens from this work (built at $80^{\circ} \mathrm{C}$ and $200{ }^{\circ} \mathrm{C}$, and tested in $\mathrm{F}$ and $\mathrm{T} 5$ conditions) compared with polished additively manufactured AlSi10Mg specimens produced at $165{ }^{\circ} \mathrm{C}$ [26] and $200{ }^{\circ} \mathrm{C}$ [21]; with conventional permanent molding (PM); and with semi-solid molding (SSM) 357 cast alloy [44] from literature. The stress ratio is $R=-1$ in all cases.

The fatigue performance found in this research is within the expected fatigue strength for Al-Si-Mg parts produced by AM, conventional casting and semi-solid casting. From the data observed, only three specimens were tested at the same stress amplitudes applied in this work. Brochu et al. [44] reported $1.51 \times 10^{4}$ cycles for one specimen (SSM-F) tested at $130 \mathrm{MPa}$; and $6.59 \times 10^{5}$ cycles and $7.33 \times 10^{5}$ cycles for specimens (SSM-T5) tested at $135 \mathrm{MPa}$ for samples tested in axial fatigue. In Mower et al. [21], polished AM AlSi10Mg specimens tested at $140 \mathrm{MPa}$ had an average fatigue life lower than specimens produced on $80^{\circ} \mathrm{C}$ and $200^{\circ} \mathrm{C}$ and tested at 135 and $130 \mathrm{MPa}$ in the present work. In contrast, comparing with Beevers et al. [26] results, specimens tested at $125 \mathrm{MPa}$ have a greater average fatigue life.

\subsection{Features Responsible for Fatigue Crack Initiation}

Optical microscopy revealed fracture surfaces typical of fatigue damage, as seen in Figure 14. The features included ridge lines converging to the crack initiation site and a beach mark at the limit of the fatigue zone and the region of final failure. For the 97 specimens tested, each fatigue failure was associated with a unique initiation site located at the surface or sub-surface of the specimen, in its gauge length. Crack initiation from 
the surface is expected in rotating-bending load configuration since the stress amplitude is maximum at the surface.

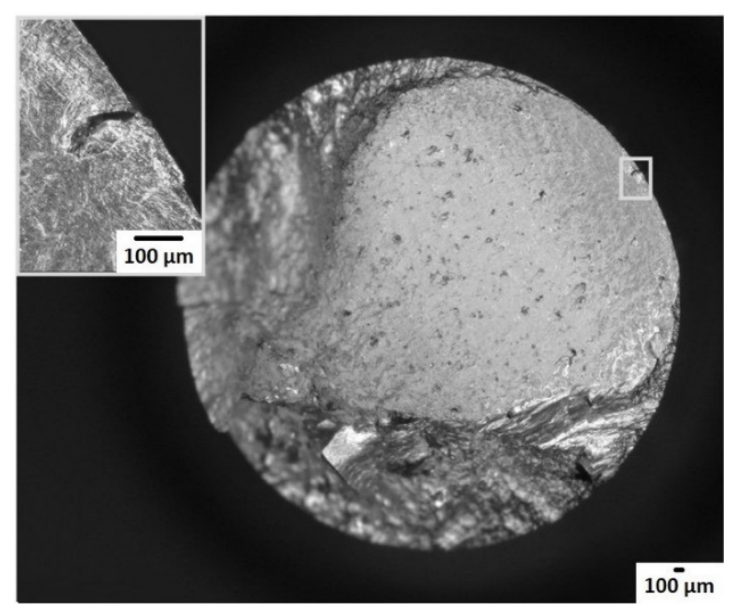

(a)

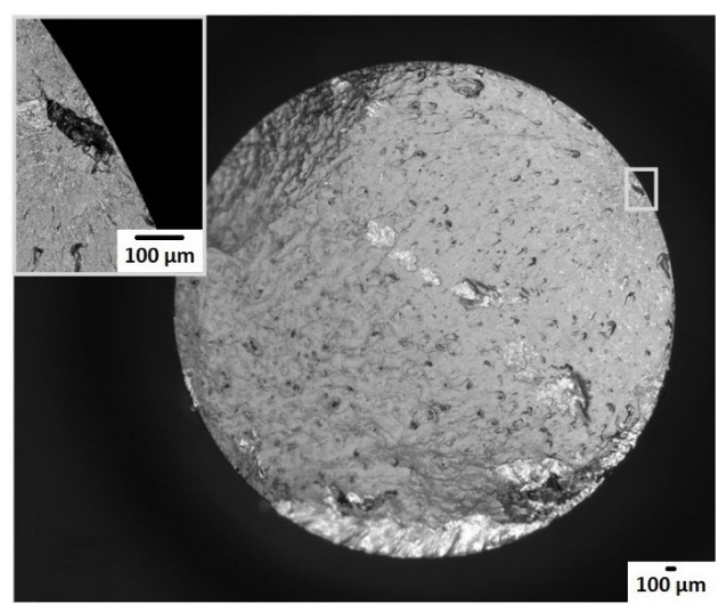

(b)

Figure 14. Digital optical microscope images of fatigue fracture surfaces $(30 \times$ and $300 \times)$. (a) Surface defect; (b) subsurface defect.

The features responsible for crack initiation were investigated using SEM. Essentially, two types of feature were observed: lack-of-fusion and oxides, as is presented in Figure 15a,b, respectively. For 11 specimens, the feature at the crack initiation site was covered by rubbing marks and thus indefinite, as shown in Figure 15c,d. Images of the crack-initiating discontinuities were captured using the SEM and their area on the fracture plane was measured as explained in the methodology (Section 2.4). Table 4 summarizes the average and range size, expressed as the square root of their area, of the discontinuities observed at the crack initiation sites. Spherical pores were also observed on the fracture surfaces, but they were not located at crack initiation sites. A comparison of the results reveal that the average size of the discontinuities measured on the $Z$ specimens is always larger than on the $X$ specimens. This is in agreement with the observations made by optical microscopy showing that the defects are elongated in the plane normal to $\mathrm{Z}$ (building direction). Another observation worth mentioning is the smaller average size of the discontinuities found on their fracture surface of the samples produced at $200{ }^{\circ} \mathrm{C}$. This difference was not revealed by the microstructural investigation.

Table 4. Summary of features and their characteristics observed at crack initiation sites.

\begin{tabular}{|c|c|c|c|c|c|}
\hline $\begin{array}{l}\text { Platform } \\
\text { Temperature }\end{array}$ & $\begin{array}{c}\text { Build } \\
\text { Direction }\end{array}$ & $\begin{array}{l}\text { Thermal } \\
\text { Condition }\end{array}$ & $\begin{array}{c}\text { Number of Specimens } \\
\text { Analyzed }\end{array}$ & $\begin{array}{l}\text { Discontinuity } \\
\text { Size }(\mu \mathrm{m})\end{array}$ & Average Size $(\mu \mathrm{m})$ \\
\hline \multirow{2}{*}{$200^{\circ} \mathrm{C}$} & $x$ & $\mathrm{~F}$ & 10 & $47-78$ & 56 \\
\hline & $\mathrm{Z}$ & $\mathrm{F}$ & 13 & $48-129$ & 84 \\
\hline \multirow{4}{*}{$35^{\circ} \mathrm{C}$} & $x$ & $F$ & 6 & $123-159$ & 128 \\
\hline & $\mathrm{Z}$ & $\mathrm{F}$ & 6 & $92-185$ & 139 \\
\hline & $x$ & T5 & 7 & $78-132$ & 95 \\
\hline & $\mathrm{Z}$ & T5 & 6 & $86-166$ & 121 \\
\hline \multirow{4}{*}{$60{ }^{\circ} \mathrm{C}$} & $x$ & $F$ & 6 & $75-129$ & 105 \\
\hline & $\mathrm{Z}$ & $\mathrm{F}$ & 5 & $64-136$ & 102 \\
\hline & $X$ & $\mathrm{~T} 5$ & 6 & $52-133$ & 98 \\
\hline & $\mathrm{Z}$ & T5 & 7 & $90-114$ & 106 \\
\hline \multirow{4}{*}{$80{ }^{\circ} \mathrm{C}$} & $x$ & F & 5 & $61-99$ & 82 \\
\hline & $\mathrm{Z}$ & $\mathrm{F}$ & 6 & $81-169$ & 129 \\
\hline & $x$ & $\mathrm{~T} 5$ & 6 & $64-137$ & 96 \\
\hline & $\mathrm{Z}$ & T5 & 6 & $94-180$ & 131 \\
\hline
\end{tabular}




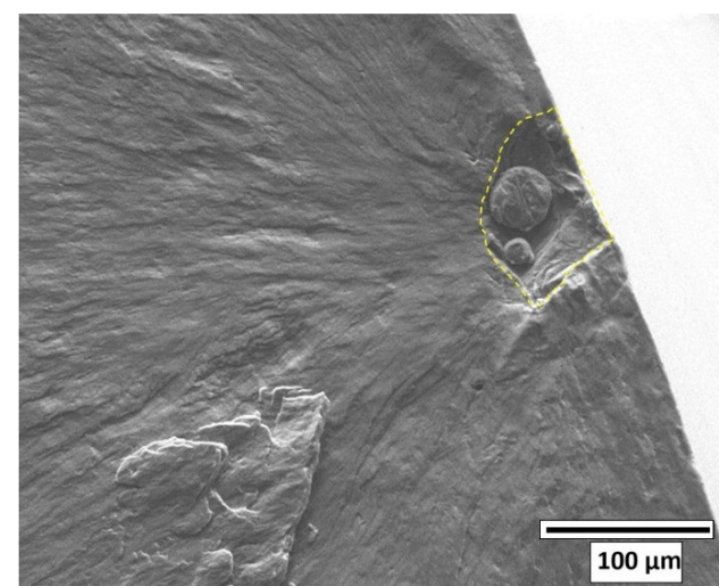

(a)

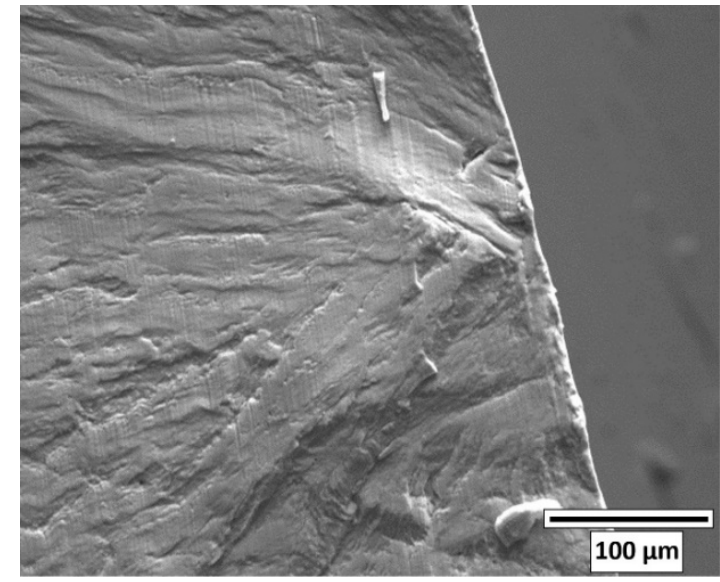

(c)

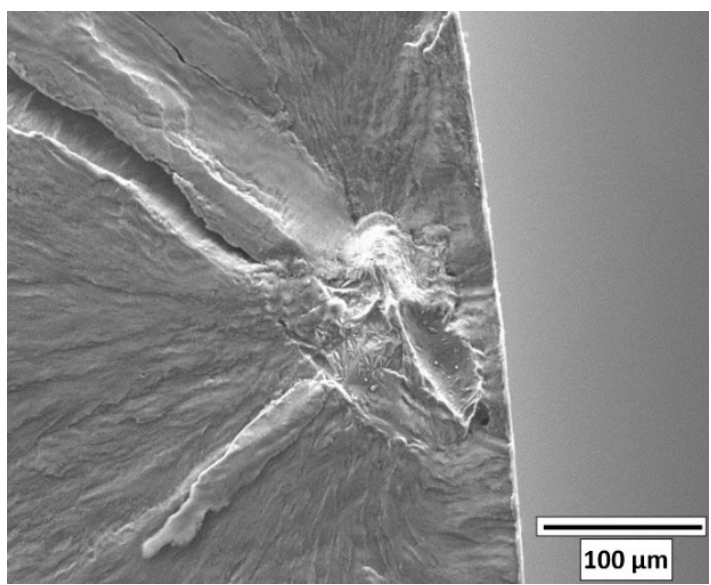

(b)

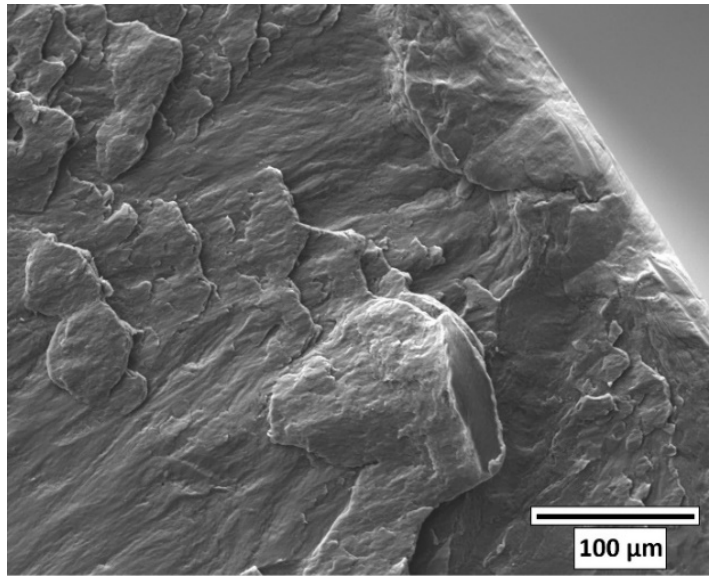

(d)

Figure 15. SEM images of fatigue fracture surfaces. Features presumed from observations to be responsible for the fatigue crack initiation: (a) lack-of-fusion $\left(N_{f}=4.41 \times 10^{5}\right.$ cycles, $\sqrt{ }$ area $\left.=104 \mu \mathrm{m}\right)$; (b) oxide $\left(N_{f}=3.25 \times 10^{6}\right.$ cycles $)$; $(\mathbf{c}, \mathbf{d})$ indefinite discontinuities.

\section{Discussion}

\subsection{Effects of Stress Intensity Factor on Fatigue Strength}

Romano et al. [7] and Tang and Pistorius [8] experimentally showed, for additively manufactured AlSi10Mg specimens, that the effect of discontinuities on fatigue life can be rationalized by calculating the maximum stress intensity range in mode $\mathrm{I}\left(K_{\mathrm{Imax}}\right)$ following the Murakami approach [39], with the expression given in Equation (2):

$$
K_{\operatorname{Imax}}=\mathrm{Y} \sigma \prime(\pi \sqrt{ } \text { area })^{1 / 2}
$$

where $\mathrm{Y}$ is a geometrical factor and $K_{\operatorname{Imax}}$ is the maximum stress intensity factor characterizing a discontinuity calculated using the local stress $\sigma^{\prime}$ at the crack tip. For residual stress-free material and a cylindrical specimen in bending, $\sigma^{\prime}$ as the following equation:

$$
\sigma^{\prime}=\sigma_{\max }\left(1-\frac{2 d}{D}\right)
$$

where $\sigma_{\max }$ is the maximum stress at the outer surface of the specimen, $d$ is the radial distance from the specimen surface to the discontinuity center; and $D$ is the diameter of the 
fracture surface (usually the diameter in the specimen gauge length). The geometrical factor $Y$ takes the values of 0.65 for surface discontinuities and 0.50 for interior discontinuities. Figures 16 and 17 present the fatigue lives of the tested specimens as a function of the $K_{\text {Imax }}$ values calculated using Equations (2) and (3) applied to the size and radial distance of the defects observed at the crack initiation site.

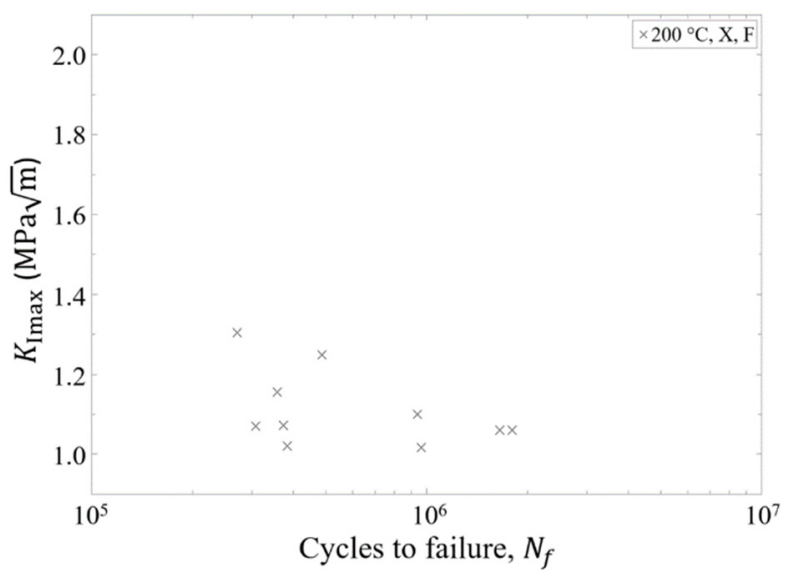

(a)

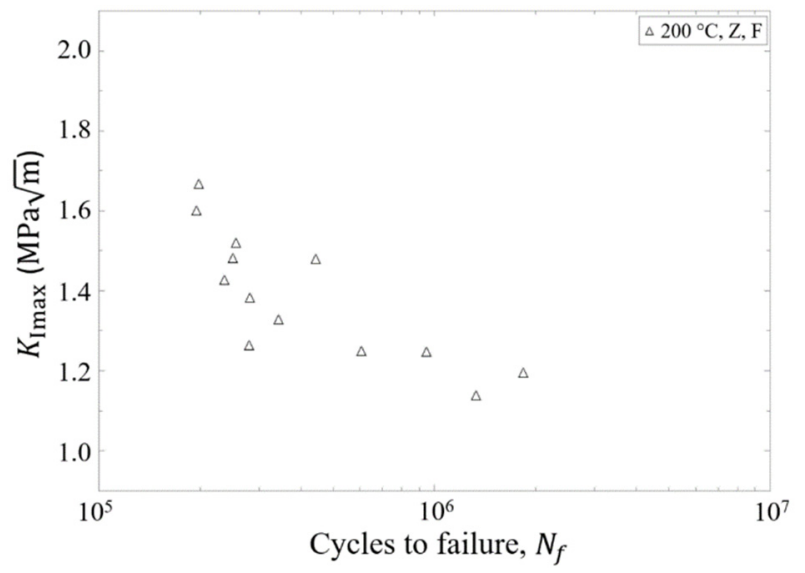

(b)

Figure 16. Fatigue results for $X(\mathbf{a})$ and $Z(\mathbf{b})$ specimens produced on a platform preheated at $200{ }^{\circ} \mathrm{C}$ presented in terms of maximum stress intensity factor $\left(K_{\text {Imax }}\right)$ characterizing defects at crack origins and number of cycles to failure $\left(N_{f}\right)$ for a stress amplitude of $130 \mathrm{MPa}$.

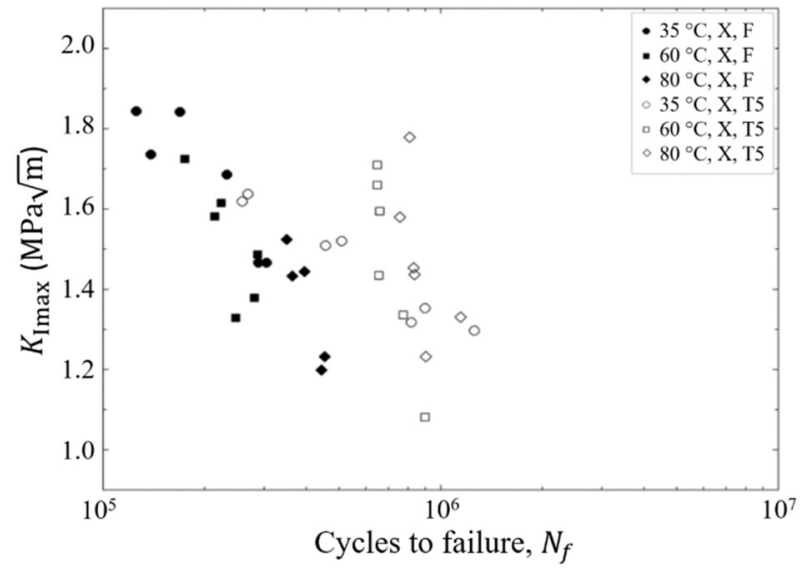

(a)

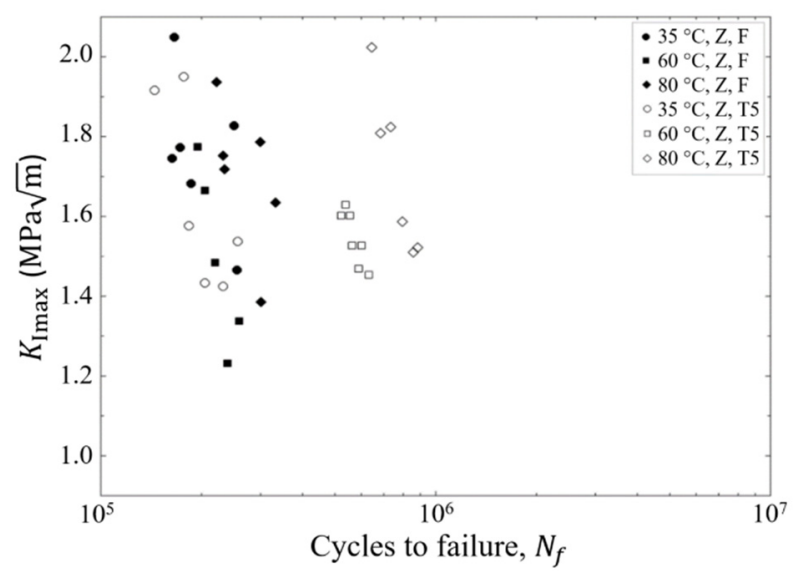

(b)

Figure 17. Fatigue results for $\mathrm{X}(\mathbf{a})$ and $Z(\mathbf{b})$ specimens produced on a platform preheated at $35{ }^{\circ} \mathrm{C}, 60{ }^{\circ} \mathrm{C}$ and $80{ }^{\circ} \mathrm{C}$ presented in terms of maximum stress intensity factor $\left(K_{\text {Imax }}\right)$ characterizing defects at crack origins and number of cycles to failure $\left(N_{f}\right)$ for a stress amplitude of $135 \mathrm{MPa}$.

The $K_{\text {Imax }}$ values of $\mathrm{X}$ and $\mathrm{Z}$ specimens confirm the anisotropic fatigue behavior of the material studied. The larger defects were systematically observed on the fracture surfaces of the $\mathrm{Z}$ specimens which lead to the maximum $K_{\operatorname{Imax}}$ value of $1.70 \mathrm{MPa} \sqrt{ } \mathrm{m}$ and $2.04 \mathrm{MPa} \sqrt{ } \mathrm{m}$, in the case of hot platform $\left(200^{\circ} \mathrm{C}-\mathrm{Z}\right)$ and cold platforms $\left(35^{\circ} \mathrm{C}-\mathrm{Z}\right)$ respectively. For the $\mathrm{X}$-built specimens, as the discontinuities are not elongated in the plane normal to the load (during bending), their projected surface areas are smaller, leading to smaller $K_{\text {Imax }}$ values and higher fatigue lives. Results presented in Table 4 confirm that X-built specimens have smaller discontinuity sizes, comparing all the average sizes of discontinuities at crack initiation sites, except for only one condition: as-built condition produced at $60{ }^{\circ} \mathrm{C}(\sqrt{ }$ area $=105 \mu \mathrm{m}$ for X-built specimens and $\sqrt{ }$ area $=102 \mu \mathrm{m}$ for Zbuilt specimens). 
The comparison of $K_{\text {Imax }}$ values also confirms that larger defect areas were observed on the fracture surfaces of the specimens produced on the cold platforms. This trend is coherent with the work of Siddique et al. [22] who showed that slower cooling rates from platform heating lead to a reduction in the number of large pores. However, reducing the cooling rate leads to a coarse dendritic microstructure as presented in Section 3.1.2.

Analyzing the results presented in Figure 17, it is apparent that for a given $K_{\text {Imax }}$, most specimens heat treated in the T5 condition failed at longer fatigue life. This is evidence that aging improved the material resistance to crack growth.

It is also of interest to analyze the $K_{\text {Imax }}$ lower bound value, as it indicates the crack propagation threshold of a material. Considering all results, this value is close to $1 \mathrm{MPa} \sqrt{ } \mathrm{m}$. In an extensive study performed on the fatigue behavior of cast and semi-solid cast 357 aluminum alloy, Brochu et al. [45] measured a long crack growth effective threshold $\left(\Delta K_{e f f, t h}\right)$ of $1.5 \mathrm{MPa} \sqrt{ } \mathrm{m}$. The results are in agreement with each other.

\subsection{Estimation of Fatigue Life by Stress Intensity Factor}

In the work of Brochu et al. [45], the tracking of crack initiation by the replica method showed that for the vast majority of the fatigue tests performed on A357 samples with polished surfaces, less than $10 \%$ of the total number of cycles to failure was attributed to crack initiation. Generalizing this observation to our results, an attempt was made to predict the fatigue lives of the specimens tested herein using the number of cycles for crack propagation, $N_{\text {prop }}$ (i.e., estimating that the number of cycles for crack initiation is 0 ). Tang and Pistorius also used such an approach in 2019 on an aluminum alloy AlSi10Mg produced by additive manufacturing. For this purpose, the Paris equation displayed in equation 4 was used with $\Delta K=K_{\text {Imax }}$ as recommended in standard ASTM E647 [46] for $R \leq 0$. The integral of equation 4 from an initial crack size equal to the square root area of the discontinuity found at the crack initiation site $\left(a_{0}=\sqrt{ }\right.$ area $)$ up to a final crack size $\left(a_{f}=a_{\mathrm{c}}\right)$ and between $N=0$ to failure $\left(N=N_{\text {fail }}\right)$ is expressed in Equation (5).

$$
\begin{gathered}
\frac{d a}{d N}=C\left(K_{\text {Imax }}\right)^{m} \\
N_{\text {fail }}=\frac{2 \sqrt{ } \text { area }}{(m-2) C\left(K_{\operatorname{Imax}}\right)^{m}}\left(1-\frac{1}{\left(\frac{a_{c}}{\sqrt{ } \text { area }}\right)^{\frac{m}{2}-1}}\right)
\end{gathered}
$$

Assuming that the final crack size $\left(a_{\mathrm{c}}\right)$ is much larger than the size of the initial discontinuity $\left(a_{0}\right)$, the first term of Equation (5) predominates and is simplified by Equation (7).

$$
\begin{gathered}
N_{\text {fail }}=\frac{2 \sqrt{ } \text { area }}{(m-2) C\left(K_{\operatorname{Imax}}\right)^{m}}=\frac{2 \sqrt{ } \text { area }}{(m-2) C\left(\mathrm{Y} \sigma \prime(\pi \sqrt{ } \text { area })^{1 / 2}\right)^{m}} \\
N_{\text {fail }}=\frac{2(\sqrt{ } \text { area })^{1-\frac{m}{2}}}{(m-2) C(\mathrm{Y} \sigma \prime)^{m}}
\end{gathered}
$$

According to the work of Brochu et al. [45], the main difference in growth kinetics for cracks propagating in different microstructures of A357 aluminum alloy is related to roughness-induced crack closure, occurring at the scale of the grain and the alpha dendrites. Based on this conclusion, the results of the hot and cold platforms were analyzed separately since the DAS was found to be larger at $200{ }^{\circ} \mathrm{C}$ when compared to the other batches. In Figures 18 and 19, graphs presenting the $\log \left(N_{\text {fail }}\right)$ as a function of the $\log (\sqrt{ }$ area $)$, are plotted to analyze the capability of this model to explain the experimental results. The model yields fair predictions when calibrated on the F and T5 conditions separately. This is different from the observations of Brochu et al. [45] who used a unique calibration for $F$ and 
T5 semi-solid cast 357 alloy. The $m$ and $C$ parameters from the Paris equation (Equation (4)) were calibrated using the fatigue results of specimens produced at $200{ }^{\circ} \mathrm{C}$ (Figure 18) and combining the results of the specimens produced at $60^{\circ} \mathrm{C}$ and $80^{\circ} \mathrm{C}$ (Figure 19) taking care to separate the F and T5 conditions. Three sets of $m$ and $C$ values, one for each batch of results, are given in Table 5, and the models are plotted as a straight line on the graphs. The values of $m$ calibrated on the fatigue results, ranges from 3.15 to 5.40. Tang and Pistorius obtained values ranging from 3.20 to 3.60 using a similar methodology applied to AlSi10Mg [8], and Brochu [45] directly measured $m$ values between 3.60 and 4.60 from long crack propagation tests.

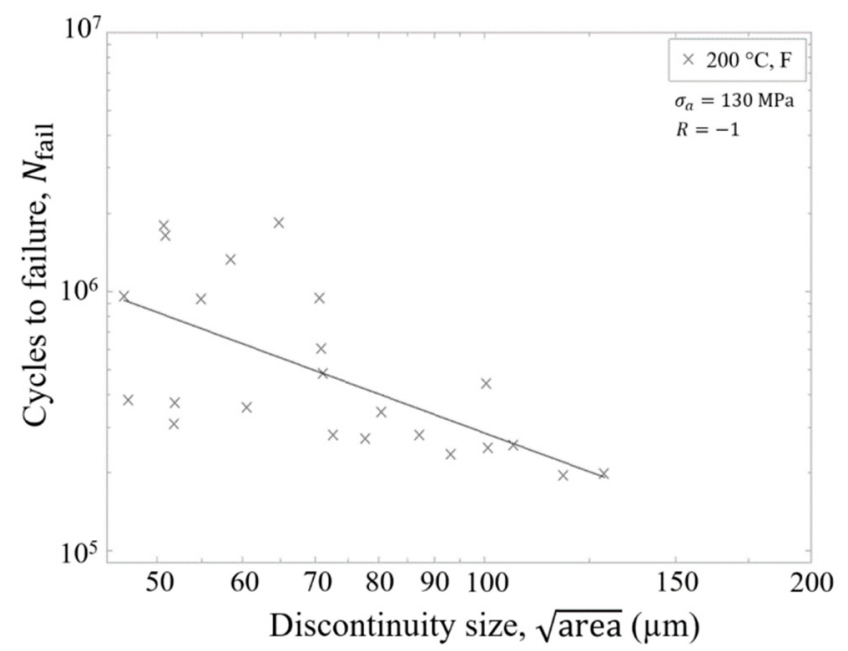

Figure 18. Relationship between number of cycles to failure $\left(N_{\text {fail }}\right)$ and discontinuity size $\sqrt{ }$ area. The fitted line represents specimens produced on $\mathrm{X}$ and Z-built conditions at $200{ }^{\circ} \mathrm{C}$. The stress amplitude is $130 \mathrm{MPa}$ and $R=-1$.

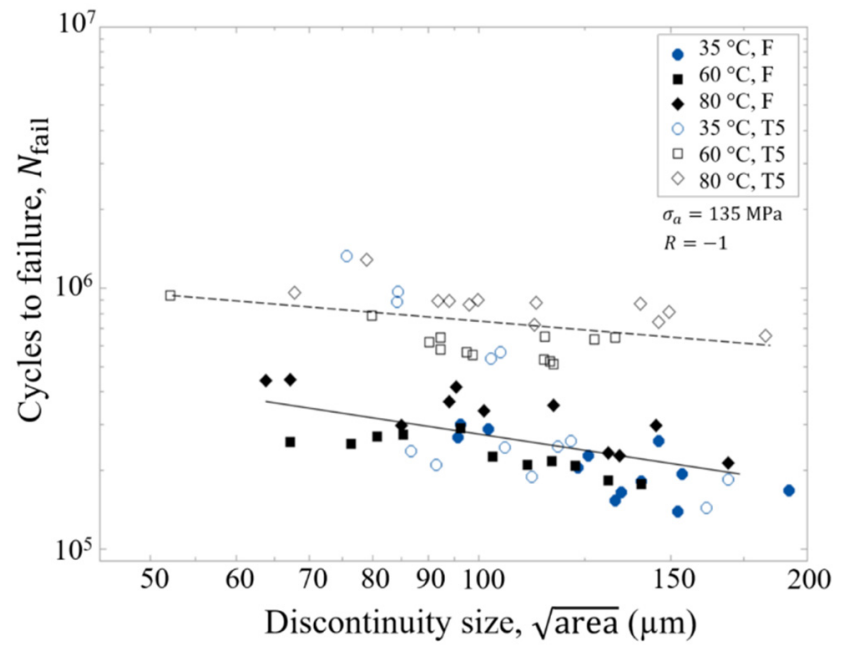

Figure 19. Relationship between number of cycles to failure $\left(N_{\text {fail }}\right)$ and discontinuity size $\sqrt{ }$ area Fitted line represents specimens produced on $X$ and Z-built conditions at $60{ }^{\circ} \mathrm{C}$ and $80{ }^{\circ} \mathrm{C}$. Filled symbols represent $\mathrm{F}$ specimens and open symbols represent $\mathrm{T} 5$ specimens. The results for the specimens produced at $35^{\circ} \mathrm{C}$ (blue circles) were added to the graph for validation purpose. For all tests, the stress amplitude is $135 \mathrm{MPa}$ and $R=-1$. 
Table 5. Paris parameters and estimated fatigue models for the additively manufactured AlSi7Mg conditions tested in this work.

\begin{tabular}{|c|c|c|c|c|c|c|}
\hline \multirow{2}{*}{$\begin{array}{c}\text { Platform } \\
\text { Temperature }\end{array}$} & \multirow{2}{*}{$\begin{array}{c}\text { Build } \\
\text { Direction }\end{array}$} & \multirow{2}{*}{$\begin{array}{l}\text { Thermal } \\
\text { Condition }\end{array}$} & \multicolumn{2}{|c|}{ Paris Parameters } & \multirow{2}{*}{$\begin{array}{c}\text { Estimated } \\
\text { Fatigue Model }\end{array}$} & \multirow{2}{*}{$\begin{array}{c}\text { Stress } \\
\text { Amplitude }\end{array}$} \\
\hline & & & $m$ & $C$ & & \\
\hline $200^{\circ} \mathrm{C}$ & $\begin{array}{l}X \\
Z\end{array}$ & F & 5.40 & $2.75 \times 10^{-11}$ & $\frac{2 \sqrt{ } \text { area }}{9.35 \times 10^{-11}\left(K_{\operatorname{Imax}}\right)^{5.40}}$ & $130 \mathrm{MPa}$ \\
\hline $\begin{array}{l}60{ }^{\circ} \mathrm{C} \\
80{ }^{\circ} \mathrm{C}\end{array}$ & $\begin{array}{l}X \\
Z\end{array}$ & $\mathrm{~F}$ & 3.34 & $1.24 \times 10^{-13}$ & $\frac{2 \sqrt{ } \text { area }}{1.66 \times 10^{-13}\left(K_{\operatorname{Imax}}\right)^{3.34}}$ & \multirow{2}{*}{$135 \mathrm{MPa}$} \\
\hline $\begin{array}{l}60{ }^{\circ} \mathrm{C} \\
80{ }^{\circ} \mathrm{C} \\
\end{array}$ & $\begin{array}{l}X \\
Z\end{array}$ & $\mathrm{~T} 5$ & 3.15 & $8.32 \times 10^{-11}$ & $\frac{2 \sqrt{ } \text { area }}{9.57 \times 10^{-11}\left(K_{\operatorname{Imax}}\right)^{3.15}}$ & \\
\hline
\end{tabular}

The results obtained for specimens built at $35^{\circ} \mathrm{C}$ were then added to the graph of Figure 19 for validation purposes. It is interesting to observe that results of the $35^{\circ} \mathrm{C}-\mathrm{F}$ samples fall close to the predictions for the other batches of $\mathrm{F}$ samples. On the other hand, the fatigue lives of most $35^{\circ} \mathrm{C}-\mathrm{T} 5$ specimens did not benefit from the heat treatment; their fatigue lives were in the same range as the F samples. This inefficiency of the T5 heat treatment to improve the fatigue lives was specifically observed for all the Z-built samples and two of the $\mathrm{X}$-built samples.

The existence of a batch of material heat treated T5 but showing fatigue lives comparable to that of as-built specimens is curious. It could be that in the presence of large defects, the defects are the first order parameter limiting resistance to fatigue which hinders the beneficial effect of precipitation hardening. Alternatively, it could be that there are other microstructural features (sharpness of discontinuities) or mechanical characteristics (residual stresses) contributing to the decrease in fatigue lives but not accounted for in this work. Siddique et al. [22] have reported that high cooling rates could introduce residual stresses. In their study [22], comparing fatigue life of specimens produced without and with heating $\left(200^{\circ} \mathrm{C}\right)$, unheated specimens had the best fatigue performance, though larger fatigue scatter. This could be a counter side for producing samples on cold platforms.

\section{Conclusions}

Rotating-bending fatigue tests were performed on polished specimens built on platforms at temperatures ranging from $35^{\circ} \mathrm{C}$ to $200^{\circ} \mathrm{C}$. The effects of the platform temperature combined with a post-processing $\mathrm{T} 5$ heat treatment on the fatigue life were surveyed. The fatigue results in combination with metallographic and fractographic observations led to the following conclusions.

- The stress amplitude to target an average fatigue life of $10^{6}$ cycles was determined to be $130 \mathrm{MPa}$ in the case of samples built on a platform heated to $200{ }^{\circ} \mathrm{C}$. This is $5 \mathrm{MPa}$ lower than the stress amplitude used to test samples built on platforms at $35^{\circ} \mathrm{C}, 60^{\circ} \mathrm{C}$ and $80{ }^{\circ} \mathrm{C}$.

- Fatigue cracks initiated from SLM manufacturing discontinuities located at the surface or just beneath the surface. These discontinuities were mainly lack of fusion ranging in size from $47 \mu \mathrm{m}$ to $185 \mu \mathrm{m}$.

- $\quad$ Specimens produced on cold platforms yielded longer fatigue lives when artificially aged. It is proposed that $\mathrm{Si}$ precipitates act as microstructural barriers to the movement of dislocations, increasing the material's resistance to crack propagation.

- The $90 \%$ probability of survival determined using a B-basis approach revealed that specimens produced on a platform maintained at $80^{\circ} \mathrm{C}$ and post-processed with a T5 heat treatment presented the highest fatigue life.

- The Paris relationship was used to predict the number of cycles needed to cause specimen failure from discontinuities. Apart from the $35^{\circ} \mathrm{C}-\mathrm{T} 5$ specimens, the prediction of fatigue lives is in good agreement with experimental results. 
This work is a further step towards fatigue life optimization and the prediction of aluminum components produced by additive manufacturing. Since defect size is the firstorder parameter for the prediction of fatigue life, the practical application of this work measurement and prediction of defect size in components.

Author Contributions: Conceptualization by L.F.L.M., M.B. (Mathieu Brochu) and M.B. (Myriam Brochu); supplied the AM samples, M.B. (Mathieu Brochu); methodology, L.F.L.M., P.R.P., M.B. (Mathieu Brochu) and M.B. (Myriam Brochu); Vickers hardness (HV) tests, L.F.L.M.; fatigue tests, L.F.L.M.; probability analysis, L.F.L.M. and P.R.P.; microstructural analyses, L.F.L.M.; fractography analyses, L.F.L.M.; fatigue life prediction, L.F.L.M., P.R.P. and M.B. (Myriam Brochu); L.F.L.M., P.R.P. and M.B. (Myriam Brochu) wrote the manuscript. All authors have read and agreed to the published version of the manuscript.

Funding: This research was funded by Bell Textron Canada Limited, Renishaw, FusiA Groupe, Pratt \& Whitney Canada, Association de l'Aluminium du Canada and AluQuébec.

Institutional Review Board Statement: Not applicable.

Informed Consent Statement: Not applicable.

Data Availability Statement: The data presented in this study are available on request from the corresponding author.

Acknowledgments: This work was financially supported by Bell Textron Canada Limited, Renishaw, FusiA Groupe, Pratt \& Whitney Canada, Association de l'Aluminium du Canada and AluQuébec. We acknowledge the support of McGill laboratories for the production of the fatigue specimens. We acknowledge Polytechnique Montreal's laboratories, the Centre for Characterization and Microscopy of Materials (CM)2 and Laboratory for Materials Preparation and Observation (LAPOM), for providing the fatigue test machine, the microscopy, and the fractography analysis. L.F. Leitao Martins is especially grateful to the Aluminum Research Centre-REGAL, who supported him and many aluminum researchers across Quebec, Canada.

Conflicts of Interest: The authors declare no conflict of interest.

\section{Appendix A}

Table A1. Table of nomenclature.

\begin{tabular}{lll}
\hline Symbol & Definition & Unit \\
\hline AM & Additive Manufacturing & - \\
DAS & Dendritic arm spacing or dendritic width & $\mu \mathrm{m}$ \\
EDM & Electrical discharge machining & - \\
F & As-built & - \\
GEV & Generalized extreme value & - \\
HCF & High-cycle fatigue & - \\
HV & Vickers microhardness & HV \\
LoF & Lack of fusion & - \\
RT & Room temperature & - \\
SEM & Scanning electron microscope & - \\
SLM & Selective Laser Melting & - \\
SR & Stress relief treatment & - \\
T5 & Artificial aging treatment & - \\
T6 & Solution annealing followed by aging treatments & - \\
$a$ & Ratio of the crack radius & $\mu \mathrm{m}$ \\
C & Paris parameter & - \\
$D$ & Specimen diameter & $\mathrm{mm}$ \\
\hline
\end{tabular}


Table A1. Cont.

\begin{tabular}{lll}
\hline Symbol & Definition & Unit \\
\hline$d$ & Distance from the specimen surface to the center of the defect & $\mu \mathrm{m}$ \\
$L$ & Machine length & $\mathrm{mm}$ \\
$m$ & Paris parameter & - \\
$N$ & Number of load cycles & cycles \\
$R$ & Stress ratio & - \\
$R^{2}$ & Coefficient of determination & - \\
$W$ & Bending load & $\mathrm{N}$ \\
$a_{0}$ & Initial crack site & $\mu \mathrm{m}$ \\
$a_{c}$ & Critical crack size & $\mu \mathrm{m}$ \\
$a_{f}$ & Final crack size & $\mu \mathrm{m}$ \\
$K_{\text {Imax }}$ & Maximum stress intensity factor in mode I & $\mathrm{MPa} \sqrt{ } \mathrm{m}$ \\
$N_{f}$ & Fatigue life & $\mathrm{cycles}$ \\
$N_{\text {fail }}$ & Number of cycles to failure & $\mathrm{cycles}$ \\
$N_{\text {prop }}$ & Number of cycles for crack propagation & $\mathrm{cycles}$ \\
$\mu$ & Scale parameter & - \\
$\sigma$ & Shape parameter & - \\
$\sigma^{\prime}$ & Local stress & $\mathrm{MPa}$ \\
$\sigma_{a}$ & Stress amplitude & $\mathrm{MPa}$ \\
$\lambda$ & Dendritic width & $\mu \mathrm{m}$ \\
$\mathrm{Y}$ & Geometrical factor & - \\
$\Delta K$ & Stress intensity range & $\mathrm{MPa} \sqrt{ } \mathrm{m}$ \\
$\Delta K_{e f f, t h}$ & Crack growth effective threshold & $\mathrm{MPa} \sqrt{ } \mathrm{m}$ \\
$\sqrt{ }$ area & Discontinuity size & $\mu \mathrm{m}$ \\
\hline & &
\end{tabular}

Table A2. Comparison of the distributions in terms of the coefficient of determination.

\begin{tabular}{ccccccc}
\hline $\begin{array}{c}\text { Platform } \\
\text { Temperature }\end{array}$ & $\begin{array}{c}\text { Build } \\
\text { Direction }\end{array}$ & $\begin{array}{c}\text { Thermal } \\
\text { Condition }\end{array}$ & GEV & $\begin{array}{c}\text { Log- } \\
\text { Normal }\end{array}$ & Normal & Weibull \\
\hline $200{ }^{\circ} \mathrm{C}$ & $\mathrm{X}$ & $\mathrm{F}$ & 0.788 & 0.945 & 0.878 & 0.888 \\
& $\mathrm{Z}$ & $\mathrm{F}$ & 0.784 & 0.953 & 0.878 & 0.892 \\
\hline $35{ }^{\circ} \mathrm{C}$ & $\mathrm{X}$ & $\mathrm{F}$ & 0.943 & 0.969 & 0.964 & 0.960 \\
& $\mathrm{Z}$ & $\mathrm{F}$ & 0.854 & 0.910 & 0.900 & 0.868 \\
& $\mathrm{X}$ & $\mathrm{T} 5$ & 0.922 & 0.976 & 0.964 & 0.962 \\
& $\mathrm{Z}$ & $\mathrm{T} 5$ & 0.977 & 0.991 & 0.992 & 0.988 \\
\hline \multirow{2}{*}{$60^{\circ} \mathrm{C}$} & $\mathrm{X}$ & $\mathrm{F}$ & 0.984 & 0.974 & 0.980 & 0.987 \\
& $\mathrm{Z}$ & $\mathrm{F}$ & 0.965 & 0.992 & 0.988 & 0.973 \\
& $\mathrm{X}$ & $\mathrm{T} 5$ & 0.785 & 0.864 & 0.858 & 0.793 \\
& $\mathrm{Z}$ & $\mathrm{T} 5$ & 0.965 & 0.993 & 0.990 & 0.972 \\
\hline${ }^{\circ} \mathrm{C}$ & $\mathrm{X}$ & $\mathrm{F}$ & 0.952 & 0.967 & 0.966 & 0.957 \\
& $\mathrm{Z}$ & $\mathrm{F}$ & 0.911 & 0.938 & 0.938 & 0.915 \\
& $\mathrm{Z}$ & $\mathrm{T} 5$ & 0.830 & 0.912 & 0.889 & 0.859 \\
\hline
\end{tabular}

Table A3. Parameters of log-normal distributions ( $\mu$ and $\sigma$ ) applied to the fatigue life results presented in Figures 9 and 10. B-basis calculated for a $90 \%$ probability of survival with a confidence level of $95 \%$.

\begin{tabular}{|c|c|c|c|c|c|c|c|}
\hline \multirow{2}{*}{$\begin{array}{c}\text { Platform } \\
\text { Temperature }\end{array}$} & \multirow{2}{*}{$\begin{array}{c}\text { Build } \\
\text { Direction }\end{array}$} & \multirow{2}{*}{$\begin{array}{l}\text { Thermal } \\
\text { Condition }\end{array}$} & \multicolumn{2}{|c|}{$\begin{array}{c}\text { Fitting Log-Normal Parameters } \\
\text { (MLE) }\end{array}$} & \multirow{2}{*}{$\begin{array}{c}\text { Average } \\
\left(\times 10^{5} \text { Cycles }\right)\end{array}$} & \multirow{2}{*}{$\begin{array}{c}\text { B-basis } \\
\left(\times 10^{5} \text { cycles }\right)\end{array}$} & \multirow[t]{2}{*}{ Stress Amplitude $\left(\sigma_{a}\right)$} \\
\hline & & & $\mu$ & $\sigma$ & & & \\
\hline \multirow{2}{*}{$200^{\circ} \mathrm{C}$} & $X$ & $\mathrm{~F}$ & 13.44 & 0.83 & 9.63 & 2.34 & \multirow{2}{*}{$130 \mathrm{MPa}$} \\
\hline & $\mathrm{Z}$ & $\mathrm{F}$ & 12.99 & 0.73 & 5.77 & 1.69 & \\
\hline
\end{tabular}


Table A3. Cont.

\begin{tabular}{|c|c|c|c|c|c|c|c|}
\hline \multirow{2}{*}{$\begin{array}{l}\text { Platform } \\
\text { Temperature }\end{array}$} & \multirow{2}{*}{$\begin{array}{c}\text { Build } \\
\text { Direction }\end{array}$} & \multirow{2}{*}{$\begin{array}{l}\text { Thermal } \\
\text { Condition }\end{array}$} & \multicolumn{2}{|c|}{$\begin{array}{l}\text { Fitting Log-Normal Parameters } \\
\text { (MLE) }\end{array}$} & \multirow{2}{*}{$\begin{array}{c}\text { Average } \\
\left(\times 10^{5} \text { Cycles }\right)\end{array}$} & \multirow{2}{*}{$\begin{array}{c}\text { B-basis } \\
\left(\times 10^{5} \text { cycles }\right)\end{array}$} & \multirow{2}{*}{ Stress Amplitude $\left(\sigma_{a}\right)$} \\
\hline & & & $\mu$ & $\sigma$ & & & \\
\hline \multirow{4}{*}{$35^{\circ} \mathrm{C}$} & $X$ & $\mathrm{~F}$ & 12.20 & 0.42 & 2.16 & 1.16 & \multirow{12}{*}{$135 \mathrm{MPa}$} \\
\hline & $\mathrm{Z}$ & $\mathrm{F}$ & 12.18 & 0.21 & 1.99 & 1.48 & \\
\hline & 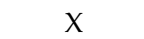 & $\mathrm{T} 5$ & 13.22 & 0.66 & 6.84 & 2.34 & \\
\hline & Z & $\mathrm{T} 5$ & 12.18 & 0.23 & 2.01 & 1.46 & \\
\hline \multirow{4}{*}{$60^{\circ} \mathrm{C}$} & $X$ & $\mathrm{~F}$ & 12.37 & 0.21 & 2.40 & 1.81 & \\
\hline & Z & $\mathrm{F}$ & 12.31 & 0.13 & 2.23 & 1.87 & \\
\hline & $X$ & T5 & 13.47 & 0.13 & 7.16 & 5.99 & \\
\hline & Z & $\mathrm{T} 5$ & 13.25 & 0.07 & 5.70 & 5.17 & \\
\hline \multirow{4}{*}{$80^{\circ} \mathrm{C}$} & $x$ & $\mathrm{~F}$ & 12.89 & 0.13 & 4.03 & 3.39 & \\
\hline & Z & $\mathrm{F}$ & 12.49 & 0.18 & 2.71 & 2.11 & \\
\hline & $X$ & T5 & 13.68 & 0.15 & 8.84 & 7.21 & \\
\hline & $\mathrm{Z}$ & T5 & 13.54 & 0.14 & 7.67 & 6.34 & \\
\hline
\end{tabular}

\section{References}

1. Military Handbook-MIL-HDBK-5H: Metallic Materials and Elements forAerospace Vehicle Structures; U.S. Department of Defense: Washington, DC, USA, 2003.

2. $\quad$ Rice, R.; Goode, R.; Bakuckas, J.; Thompson, S.; Hughes, W.; Patterson, W. Development of MMPDS Handbook Aircraft Design Allowables. 2003. Available online: http:/ / citeseerx.ist.psu.edu/viewdoc/download?doi=10.1.1.545.9914\&rep=rep1\&type=pdf (accessed on 20 April 2021).

3. Tang, M.; Pistorius, P.C. Oxides, porosity and fatigue performance of AlSi10Mg parts produced by selective laser melting. Int. J. Fatigue 2017, 94, 192-201. [CrossRef]

4. Uzan, N.E.; Shneck, R.; Yeheskel, O.; Frage, N. Fatigue of AlSi10Mg specimens fabricated by additive manufacturing selective laser melting (AM-SLM). Mater. Sci. Eng. A 2017, 704, 229-237. [CrossRef]

5. Yang, K.; Rometsch, P.; Jarvis, T.; Rao, J.; Cao, S.; Davies, C.; Wu, X. Porosity formation mechanisms and fatigue response in Al-Si-Mg alloys made by selective laser melting. Mater. Sci. Eng. A 2017, 712. [CrossRef]

6. Zhang, C.; Zhu, H.; Liao, H.; Cheng, Y.; Hu, Z.; Zeng, X. Effect of heat treatments on fatigue property of selective laser melting AlSi10Mg. Int. J. Fatigue 2018, 116. [CrossRef]

7. Romano, S.; Bruckner-Foit, A.; Brandao, A.; Gumpinger, J.; Ghidini, T.; Beretta, S. Fatigue properties of AlSi10Mg obtained by additive manufacturing: Defect-based modelling and prediction of fatigue strength. Eng. Fract. Mech. 2018, 187, 165-189. [CrossRef]

8. Tang, M.; Pistorius, P.C. Fatigue life prediction for AlSi10Mg components produced by selective laser melting. Int. J. Fatigue 2019, 125, 479-490. [CrossRef]

9. Domfang Ngnekou, J.N.; Nadot, Y.; Henaff, G.; Nicolai, J.; Kan, W.H.; Cairney, J.M.; Ridosz, L. Fatigue properties of AlSi10Mg produced by Additive Layer Manufacturing. Int. J. Fatigue 2019, 119, 160-172. [CrossRef]

10. Röttger, A.; Boes, J.; Theisen, W.; Thiele, M.; Esen, C.; Edelmann, A.; Hellmann, R. Microstructure and mechanical properties of 316L austenitic stainless steel processed by different SLM devices. Int. J. Adv. Manuf. Technol. 2020, 108, 769-783. [CrossRef]

11. Andreau, O.; Pessard, E.; Koutiri, I.; Peyre, P.; Saintier, N. Influence of the position and size of various deterministic defects on the high cycle fatigue resistance of a 316L steel manufactured by laser powder bed fusion. Int. J. Fatigue 2020, 143. [CrossRef]

12. Petroušek, P.; Bidulská, J.; Bidulský, R.; Kočiško, R.; Fedorikova Rozsypalova, A.; Hudak, R.; Rajtukova, V.; Zivcak, J. Mechanical properties and porosity of Ti-6Al-4V alloy prepared by AM technology. MM Sci. J. 2017, 2017, 1752-1755. [CrossRef]

13. Ellyson, B.; Brochu, M.; Brochu, M. Characterization of bending vibration fatigue of SLM fabricated Ti-6Al-4V. Int. J. Fatigue 2017, 99, 25-34. [CrossRef]

14. Pessard, E.; Lavialle, M.; Laheurte, P.; Didier, P.; Brochu, M. High-cycle fatigue behavior of a laser powder bed fusion additive manufactured Ti-6Al-4V titanium: Effect of pores and tested volume size. Int. J. Fatigue 2021, 106206. [CrossRef]

15. Persenot, T.; Burr, A.; Dendievel, R.; Buffière, J.-Y.; Maire, E.; Lachambre, J.; Martin, G. Fatigue performances of chemically etched thin struts built by selective electron beam melting: Experiments and predictions. Materialia 2020, 9, 100589. [CrossRef]

16. Polozov, I.; Popovich, A.; Sufiiarov, V.; Borisov, E. Microstructure and Mechanical Properties of Inconel 718 Produced by SLM and Subsequent Heat Treatment. Key Eng. Mater. 2015, 651-653, 665-670. [CrossRef]

17. Brandl, E.; Heckenberger, U.; Holzinger, V.; Buchbinder, D. Additive manufactured AlSi10Mg samples using Selective Laser Melting (SLM): Microstructure, high cycle fatigue, and fracture behavior. Mater. Des. 2012, 34, 159-169. [CrossRef]

18. Casati, R.; Hamidi Nasab, M.; Coduri, M.; Tirelli, V.; Vedani, M. Effects of Platform Pre-Heating and Thermal-Treatment Strategies on Properties of AlSi10Mg Alloy Processed by Selective Laser Melting. Metals 2018, 8, 954. [CrossRef]

19. Casati, R.; Vedani, M. Aging Response of an A357 Al Alloy Processed by Selective Laser Melting. Adv. Eng. Mater. 2018, 21. [CrossRef]

20. Kimura, T.; Nakamoto, T. Microstructures and mechanical properties of A356 (AlSi7Mg0.3) aluminum alloy fabricated by selective laser melting. Mater. Des. 2015, 89. [CrossRef] 
21. Mower, T.M.; Long, M.J. Mechanical behavior of additive manufactured, powder-bed laser-fused materials. Mater. Sci. Eng. A 2016, 651, 198-213. [CrossRef]

22. Siddique, S.; Imran, M.; Wycisk, E.; Emmelmann, C.; Walther, F. Influence of process-induced microstructure and imperfections on mechanical properties of AlSi12 processed by selective laser melting. J. Mater. Process. Technol. 2015, 221, 205-213. [CrossRef]

23. Tang, M.; Pistorius, P. Anisotropic Mechanical Behavior of AlSi10Mg Parts Produced by Selective Laser Melting. JOM 2017, 69. [CrossRef]

24. Wang, M.; Song, B.; Wei, Q.; Zhang, Y.; Shi, Y. Effects of annealing on the microstructure and mechanical properties of selective laser melted AlSi7Mg alloy. Mater. Sci. Eng. A 2019, 739, 463-472. [CrossRef]

25. Aboulkhair, N.T.; Maskery, I.; Tuck, C.; Ashcroft, I.; Everitt, N.M. Improving the fatigue behaviour of a selectively laser melted aluminium alloy: Influence of heat treatment and surface quality. Mater. Des. 2016, 104, 174-182. [CrossRef]

26. Beevers, E.; Brandao, A.D.; Gumpinger, J.; Gschweitl, M.; Seyfert, C.; Hofbauer, P.; Rohr, T.; Ghidini, T. Fatigue properties and material characteristics of additively manufactured AlSi10Mg Effect of the contour parameter on the microstructure, density, residual stress, roughness and mechanical properties. Int. J. Fatigue 2018, 117, 148-162. [CrossRef]

27. Yan, Q.; Song, B.; Shi, Y. Comparative study of performance comparison of AlSi10Mg alloy prepared by selective laser melting and casting. J. Mater. Sci. Technol. 2020, 41, 199-208. [CrossRef]

28. Bagherifard, S.; Beretta, N.; Monti, S.; Riccio, M.; Bandini, M.; Guagliano, M. On the fatigue strength enhancement of additive manufactured AlSi10Mg parts by mechanical and thermal post-processing. Mater. Des. 2018, 145. [CrossRef]

29. Boniotti, L.; Beretta, S.; Patriarca, L.; Rigoni, L.; Foletti, S. Experimental and numerical investigation on compressive fatigue strength of lattice structures of AlSi7Mg manufactured by SLM. Int. J. Fatigue 2019, 128, 105181. [CrossRef]

30. Hamidi Nasab, M.; Romano, S.; Gastaldi, D.; Beretta, S.; Vedani, M. Combined effect of surface anomalies and volumetric defects on fatigue assessment of AlSi7Mg fabricated via laser powder bed fusion. Addit. Manuf. 2020, 34. [CrossRef]

31. Casati, R.; Hamidi Nasab, M.; Vedani, M. Effect of Different Heat Treatment Routes on Microstructure and Mechanical Properties of AlSi7Mg, AlSi10Mg and Al-Mg-Zr-Sc Alloys Produced by Selective Laser Melting. 2018. Available online: https:/ / www.researchgate.net/profile/Milad-Hamidi-Nasab/publication/327437204_Effect_of_Different_Heat_Treatment_ Routes_on_Microstructure_and_Mechanical_Properties_of_AlSi7Mg_AlSi10Mg_and_Al-Mg-Zr-Sc_Alloys_Produced_by_ Selective_Laser_Melting/links/5b8f9fb145851540d1c9ee6d/Effect-of-Different-Heat-Treatment-Routes-on-Microstructure-andMechanical-Properties-of-AlSi7Mg-AlSi10Mg-and-Al-Mg-Zr-Sc-Alloys-Produced-by-Selective-Laser-Melting.pdf (accessed on 20 April 2021).

32. Kearney, A.L. Properties of Cast Aluminum Alloys. In Properties and Selection: Nonferrous Alloys and Special-Purpose Materials; ASM Handbook Committee, Ed.; ASM International: West Conshohocken, PA, USA, 1990; Volume 2, pp. 152-177.

33. ASTM International. ASTM B108/B108M-19 Standard Specification for Aluminum-Alloy Permanent Mold Castings; ASTM International: West Conshohocken, PA, USA, 2019. [CrossRef]

34. ASTM International. ASTM E466-15 Standard Practice for Conducting Force Controlled Constant Amplitude Axial Fatigue Tests of Metallic Materials; ASTM International: West Conshohocken, PA, USA, 2015. [CrossRef]

35. International Organization for Standardization. ISO 1143:2010 Metallic Materials—Rotating Bar Bending Fatigue Testing; ISO: Geneva, Switzerland, 2010.

36. Anderson, T.W. Anderson-Darling Tests of Goodness-of-Fit. In International Encyclopedia of Statistical Science; Lovric, M., Ed.; Springer: Berlin/Heidelberg, Germany, 2011; pp. 52-54. [CrossRef]

37. Dowling, N.E. Mechanical Behavior of Materials: Engineering Methods for Deformation, Fracture, and Fatigue, 4th ed.; Pearson: Boston, MA, USA, 2013.

38. Bag, A.; Delbergue, D.; Ajaja, J.; Bocher, P.; Lévesque, M.; Brochu, M. Effect of different shot peening conditions on the fatigue life of 300M steel submitted to high stress amplitudes. Int. J. Fatigue 2019, 130, 105274. [CrossRef]

39. Murakami, Y. Metal Fatigue: Effects of Small Defects and Nonmetallic Inclusions; Elsevier: Amsterdam, The Netherlands, 2002.

40. Skallerud, B.; Iveland, T.; Härkegård, G. Fatigue life assessment of aluminum alloys with casting defects. Eng. Fract. Mech. 1993, 44, 857-874. [CrossRef]

41. Barter, S.; Molent, L.; Goldsmith, N.; Jones, R. An experimental evaluation of fatigue crack growth. Eng. Fail. Anal. 2005, 12, 99-128. [CrossRef]

42. Saberifar, S.; Mashreghi, A.R.; Mosalaeepur, M.; Ghasemi, S.S. The interaction between non-metallic inclusions and surface roughness in fatigue failure and their influence on fatigue strength. Mater. Des. 2012, 35, 720-724. [CrossRef]

43. ASTM International. ASTM E112-13 Standard Test Methods for Determining Average Grain Size; ASTM International: West Conshohocken, PA, USA, 2013. [CrossRef]

44. Brochu, M.; Bouchard, D.; Verreman, Y.; Ajersch, F. High cycle fatigue strength of permanent mold and rheocast aluminum alloy 357. Int. J. Fatigue 2010, 32. [CrossRef]

45. Brochu, M. Comportement en Fatigue de l'Luminium 357 coulé par Gravité et Rhéocoulé. Ph.D. Thesis, Ecole Polytechnique, Montreal, QC, Canada, 2010.

46. ASTM International. ASTM E647-15e1 Standard Test Method for Measurement of Fatigue Crack Growth Rates; ASTM International: West Conshohocken, PA, USA, 2015. [CrossRef] 